\title{
Article \\ Genotype-Dependent Tipburn Severity during Lettuce Hydroponic Culture Is Associated with Altered Nutrient Leaf Content
}

\author{
Virginia Birlanga ${ }^{1}$, José Ramón Acosta-Motos ${ }^{2,3}$ (D) and José Manuel Pérez-Pérez ${ }^{4, *(D)}$ \\ 1 Monsanto Agricultura España S.L.U., 30319 Miranda, Spain; virginia.birlanga@bayer.com \\ 2 Group of Fruit Tree Biotechnology, CEBAS-CSIC, 30100 Murcia, Spain; jacosta@cebas.csic.es \\ 3 Cátedra Emprendimiento en el Âmbito Agroalimentario, Campus de los Jerónimos, \\ Universidad Católica San Antonio de Murcia (UCAM), No. 135 Guadalupe, 30107 Murcia, Spain \\ 4 Instituto de Bioingeniería, Universidad Miguel Hernández, 03202 Elche, Spain \\ * Correspondence: jmperez@umh.es; Tel.: +34-966-658-958
}

Citation: Birlanga, V.; Acosta-Motos, J.R.; Pérez-Pérez, J.M.

Genotype-Dependent Tipburn Severity during Lettuce Hydroponic Culture Is Associated with Altered Nutrient Leaf Content. Agronomy 2021, 11, 616. https://doi.org/ 10.3390/agronomy11040616

Academic Editor: Dimitrios Savvas

Received: 4 February 2021

Accepted: 22 March 2021

Published: 24 March 2021

Publisher's Note: MDPI stays neutral with regard to jurisdictional claims in published maps and institutional affiliations.

Copyright: (c) 2021 by the authors. Licensee MDPI, Basel, Switzerland. This article is an open access article distributed under the terms and conditions of the Creative Commons Attribution (CC BY) license (https:// creativecommons.org/licenses/by/ $4.0 /)$.

\begin{abstract}
Cultivated lettuce (Lactuca sativa L.) is one of the most important leafy vegetables in the world, and most of the production is concentrated in the Mediterranean Basin. Hydroponics has been successfully utilized for lettuce cultivation, which could contribute to the diversification of production methods and the reduction of water consumption and excessive fertilization. We devised a low-cost procedure for closed hydroponic cultivation and easy phenotyping of root and shoot attributes of lettuce. We studied 12 lettuce genotypes of the crisphead and oak-leaf subtypes, which differed on their tipburn resistance, for three growing seasons (Fall, Winter, and Spring). We found interesting genotype $\times$ environment $(G \times E)$ interactions for some of the studied traits during early growth. By analyzing tipburn incidence and leaf nutrient content, we were able to identify a number of nutrient traits that were highly correlated with cultivar- and genotype-dependent tipburn. Our experimental setup will allow evaluating different lettuce genotypes in defined nutrient solutions to select for tipburn-tolerant and highly productive genotypes that are suitable for hydroponics.
\end{abstract}

Keywords: Lactuca sativa L.; crisphead; oak-leaf; root system architecture; tipburn; nutritional imbalance

\section{Introduction}

Cultivated lettuce (Lactuca sativa L.; Asteraceae), which is usually consumed fresh, is one of the most important leafy vegetables in the world. Commercial lettuce varieties are classified based on head and leaf characteristics, and some of the most common horticultural types are romaine, iceberg (also named as crisphead; CHD), oak-leaf (i.e., green oak; GOAK, and red oak; ROAK), and butterhead. Breeding new lettuce cultivars involves manual pollination of genetically stable (i.e., pure) parent lines with agronomic traits of interest, followed by selection based on plant phenotyping and genotyping [1,2]. The availability of detailed genetic maps of cultivated lettuce [3-7] has allowed significant progress for mapping agronomically-important traits and promoted the development of marker-assisted selection (MAS) and candidate gene identification in these species [8]. Several studies have shown that most breeding target traits, such as disease resistance [9], postharvest discoloration [10], thermotolerance in seed germination [7], or water and nitrate capture [6], are complex traits and thus controlled by quantitative trait loci (QTL).

Spain is the third-largest producer of lettuce and chicory in the world after China and the USA, with a total of c.a. 1.1 million tons, with an area of 35,360 hectares dedicated for their cultivation [11]. Most of the production is focused on the southeastern Mediterranean region, with a temperate climate that allows lettuce cultivation throughout the year, making Spain the world's largest lettuce exporting country. However, water scarcity and soil availability are limiting factors for plant cultivation, and inadequate irrigation and fertilization management has increased the environmental impact of agricultural exploitation in this 
region $[12,13]$. Therefore, to contribute to sustainable lettuce production, there is a strong requirement for the development of new forms of farming to increase the crop's resource use efficiency and the reduction of production costs. Floating systems or closed hydroponic methods have been successfully engaged for lettuce cultivation [14-16]. This technique allows for the precise control of water and mineral nutrition, saves soil and labor costs, and provides shorter harvest cycles, high product quality, and good consumer acceptance [16].

Tipburn is defined as the localized necrosis found on the distal margins of rapidly expanding leaves. It is a serious problem in controlled lettuce production, as it reduces the quality and shelf life of fresh lettuce, hence resulting in severe economic losses [17-19]. Tipburn is influenced by many environmental factors, such as light intensity, air temperature, and soil conditions, and is considered a calcium deficiency-related physiological disorder, which is usually associated with rapidly growing tissues $[17,18,20,21]$. In addition, a strong variation for tipburn incidence among different lettuce cultivars has been reported [19,22], allowing for the development of tipburn-resistant varieties $[19,23,24]$. The use of genomic tools has enabled the identification of QTL for tipburn incidence in several recombinant inbred line (RIL) populations and the development of linked molecular markers [25,26]. However, further research is needed to identify the underlying candidate genes for these QTL and the effect of their introgression into other lettuce cultivars. Also, only a few studies on tipburn incidence have been carried out in lettuce grown in hydroponics $[27,28]$.

Within the framework of a company-based breeding program for lettuce, we devised a low-cost procedure for closed hydroponic cultivation and easy phenotyping of root and shoot attributes during early growth in three growing seasons (Fall, Winter, and Spring). A representative sample of lettuce varieties from different cultivars (CHD, GOAK and ROAK) were selected based on contrasting agronomically relevant traits such as tipburn tolerance. Our results allowed us to define genotype $\times$ environment $(G \times E)$ interactions for some of the studied traits, and to establish a strong correlation between leaf nutrient content and tipburn incidence, which may help to reduce leaf damage through adequate fertilization management.

\section{Materials and Methods}

\subsection{Plant Material and Growth Conditions}

We selected 12 lettuce genotypes from the breeding program at Monsanto Agriculture Spain S.L.U. (Murcia, Spain) which differed on their tipburn resistance as visually scored at the company's experimental station ( $37^{\circ} 41^{\prime} 47.6^{\prime \prime} \mathrm{N} 1^{\circ} 01^{\prime} 55.2^{\prime \prime} \mathrm{W}$, Murcia, Spain; Table 1). We included four genotypes of the Lactuca sativa var. capitata L., hereafter referred as crisphead (CHD) or iceberg cultivar; and eight genotypes from Lactuca sativa var. crispa L., which differed in their leaf color, and which were assigned either to the green oak (GOAK) or to the red oak (ROAK) subtypes (Table 1). Seeds from the cultivars used in this work are available upon request to V.B.

Seedlings were sown in 198-well trays filled with moistened $80 \%$ perlite and $20 \%$ substrate (FloraGard) and were incubated in darkness for 3 days at $10 \pm 2{ }^{\circ} \mathrm{C}$ and $75 \%$ relative humidity. Germinated trays were transferred to the nursery chamber set at $20 \pm 2{ }^{\circ} \mathrm{C}, 65 \%$ relative humidity, and under natural photoperiod (Table S1) until the seedlings had 2-3 true leaves (10 mm; Figure 1a). For each cultivar and experiment, eight randomly-selected seedlings were then transferred to $3 \mathrm{~L}$ sealed and opaque pots filled with nutrient solution [29] (Table S2); with an eventual air pump $(5 \times 2.5$ L) for hydroponic growth [30] in a multi-tunnel greenhouse at the company's experimental station and under environmental conditions ( 0 days after planting, dap; Figure $1 \mathrm{~b}$ ). As previous results indicated that lettuce growth was strongly affected by $\mathrm{N}$ application [17], we adjusted the nutrient solution for optimal $\mathrm{N}$ supply. To avoid contamination, the nutrient solution was renewed every two weeks. 
Table 1. Some details of the lettuce genotypes used in this study.

\begin{tabular}{cccc}
\hline Cultivar & Genotype & Description & Tipburn Phenotype [18] \\
\hline CHD & C1 & Collected in Summer, crispy leaves & Light \\
\hline CHD & C7 & $\begin{array}{c}\text { Collected in late Fall, dark green leaves and } \\
\text { ovate leaves, big size head }\end{array}$ & Severe \\
\hline CHD & C8 & $\begin{array}{c}\text { Collected in Winter, dark green leaves and } \\
\text { ovate leaves, big size head }\end{array}$ & Medium \\
\hline CHD & G1 & $\begin{array}{c}\text { Collected in late Fall, medium-size head } \\
\text { Voluminous and compact lettuce, strong } \\
\text { against bolting }\end{array}$ & Ledium \\
\hline GOAK & G3 & $\begin{array}{c}\text { Collected in Winter and Spring, indoor and } \\
\text { outdoor production. Round shape, dense } \\
\text { filling, high weight, strong against bolting }\end{array}$ & Severe \\
\hline GOAK & G5 & $\begin{array}{c}\text { Collected in Spring and Fall, upright and } \\
\text { compact leaves, slow bolting }\end{array}$ & Light \\
\hline GOAK & G6 & $\begin{array}{c}\text { Collected in Spring and Summer, indoor } \\
\text { production, dark green color, strong } \\
\text { against bolting }\end{array}$ & Medium \\
GOAK & R2 & $\begin{array}{c}\text { Collected in Fall and Winter, slight red, } \\
\text { small and bit cylindrical heads }\end{array}$ & Severe \\
\hline ROAK & R3 & $\begin{array}{c}\text { Collected in Fall and Spring, dark green } \\
\text { color, medium volume }\end{array}$ & Medium \\
\hline ROAK & R4 & Collected in Fall, good vigor and volume & Light \\
\hline ROAK & R5 & $\begin{array}{c}\text { Collected in Fall and Spring, good vigor } \\
\text { and volume, strong against bolting }\end{array}$ & Light \\
\hline ROAK & &
\end{tabular}
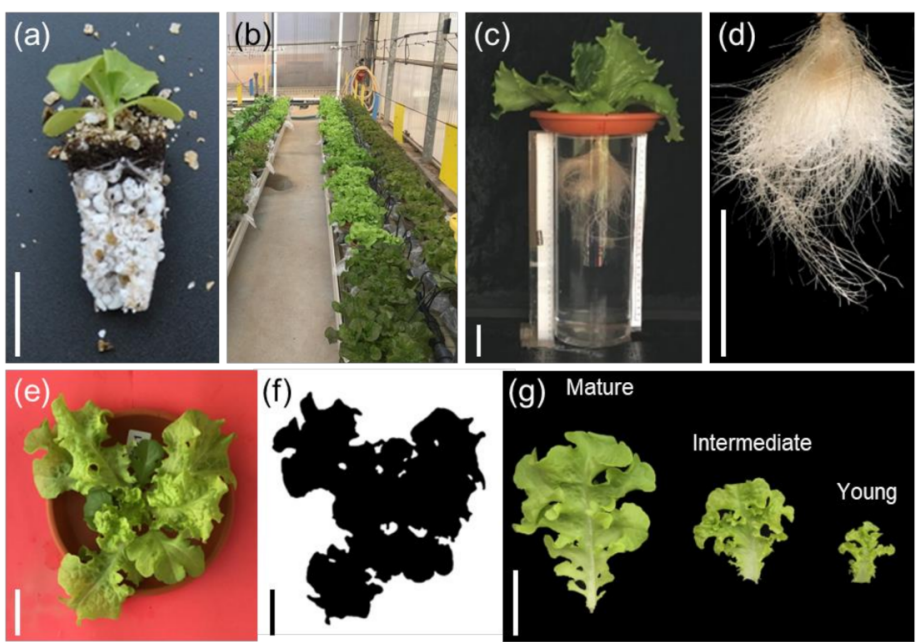

Figure 1. Experimental design for studying growth, tipburn phenotypes, and nutrient concentrations in different lettuce genotypes. (a) A representative image of a young seedling from the nursery chamber. (b) General view of the hydroponic system used for lettuce cultivation at the experimental station. (c) Glass cylinder vase used for image acquisition. (d,e) A representative image of the roots (d) and the shoot (e) of a plant grown in hydroponics for 21 days. (f) Image segmentation files obtained with Image J software. (g) A representative image of leaves collected for nutrient concentration analysis. Scale bars: $50 \mathrm{~mm}$. 


\subsection{Image Analysis}

Five randomly chosen plants were periodically taken for image analyses during the hydroponic culture at $0,7,14,21,28,35$, and 45 dap. To minimize light variation, a photography box was used with illumination from below. Plants were transferred to a glass cylinder vase $(12 \times 28 \mathrm{~cm})$ filled with nutrient solution (Figure 1c) and their root and shoot system were respectively imaged (Figure 1d,e) with a still smartphone camera (iPhone 6s, 12 MP f2.2) and saved as an RGB color image in jpeg format $(1200 \times 2800$ pixels). Root area (RA) was measured using the GiA Roots software [31] as described elsewhere [32]. For the shoot area (SA) measurement, the background of the image was removed using Adobe Photoshop CS3, and images were batch-processed using Image J [33] (Figure 1f). Raw measurements were exported to Excel spreadsheets for data analysis.

\subsection{Tipburn Evaluation}

From 14 dap onwards, tipburn severity (TS) was assessed weekly in individual plants by scoring the presence of necrotic symptoms on the edges of leaves on a scale from 1 to 9 , where 1 was no tipburn and 9 was severe tipburn (Figure S1). To obtain these scores, five plants were evaluated per cultivar and season. In addition, tipburn incidence (TBI) was calculated to verify agreement with TS as previously described in [18] with the following formula:

$\mathrm{TBI}=\frac{(\mathrm{n} \text { plants severe tipburn } \times 5+\mathrm{n} \text { plants medium tipburn } \times 3+\mathrm{n} \text { plants light tipburn })}{\mathrm{n} \text { plants } \times 5} \times 100$

\subsection{Growth Parameters and Nutrient Content Analysis}

At the end of the experiment (45 dap), each plant was separated into shoots and roots to measure their fresh weight (FW). Dry weight (DW) was measured in samples that were oven-dried at $80^{\circ} \mathrm{C}$ for $72 \mathrm{~h}$. Root and leaf water content (WC) were determined as: $\frac{(\mathrm{FW}-\mathrm{DW})}{\mathrm{FW}} \times 100$. Stem length and leaf number were also documented.

For nutrient concentration analysis, we randomly selected three 21 dap plants from the Spring season, and mature (M), intermediate (I), and juvenile (J) leaves were collected from each plant and imaged for SA determination (see Section 2.2; Figure 1g). FW, DW, and WC were measured as described above.

The measurement of different macronutrients: potassium $(\mathrm{K})$, calcium $(\mathrm{Ca})$, phosphorus $(\mathrm{P})$, sulfur $(\mathrm{S})$, magnesium $(\mathrm{Mg})$, sodium $(\mathrm{Na})$, and micronutrients: iron $(\mathrm{Fe})$, manganese $(\mathrm{Mn})$, zinc $(\mathrm{Zn})$, copper $(\mathrm{Cu})$, was carried out in a digestion extract containing $100 \mathrm{mg}$ of tissue powder and $50 \mathrm{~mL}$ of a mix of $\mathrm{HNO}_{3}: \mathrm{HClO}_{4}(2: 1 v / v)$ using an inductively coupled plasma optical emission spectrometer (ICP-OES IRIS INTREPID II XDL, Thermo Fisher Scientific Inc., Loughborough, UK) at the Ionomic Services of the CEBAS-CSIC (Murcia, Spain) [34].

\subsection{Statistical Analysis}

The descriptive statistics (mean, standard error of the mean (SEM), etc.) calculated for samples and different tests described below were performed by using the StatGraphics Centurion XV software (StatPoint Technologies, Inc., Warrenton, VA, USA). The KolmogorovSmirnov [35] and Shapiro tests were performed to check the normality of the data by analyzing the goodness-of-fit between the distribution of the data and a given theoretical normal distribution. In addition, to check the homogeneity of the variance, the Bartlett and Levene tests were applied. The data with a normal distribution were analyzed by a one-way ANOVA followed by Fisher's LSD (least significant differences) multiple range Test [36] to separate the treatment means, thereby detecting significant differences ( $p$-value $<0.01$ ). Non-parametric tests were used when necessary. In that case, the median was used instead of the mean, and the data were subjected to the Kruskal-Wallis test ( $p$-value $<0.01$ ). Heatmaps were processed using the pheatmap package in R [37]. Neighbor-joining distance matrixes between genotypes (rows) and between samples (columns) were automatically 
calculated from average values to build the dendrograms and the heatmap representation. Graphs were drawn with GraphPad Prism 9.0.0 for Windows (GraphPad Software, San Diego, CA, USA).

\section{Results}

\subsection{Quantitative Analysis of Root and Shoot Area during Hydroponic Growth}

We followed the growth of the studied lettuce cultivars grown on hydroponic culture by periodically imaging the root and the shoot system between 0 and 35 dap (see Section 2). Estimated root and shoot areas (RA and SA) in the studied CHD genotypes exponentially increased between 0 and 35 dap, following a season-dependent pattern ( $p$-value $=0.002$; Figure 2a,b and Table S3). The highest growth rate of the RA occurred during Spring for C3 (Figure S2). Instead, C1 and C7 showed the highest SA growth rate during Fall (Figure S2). In all seasons, C7 and C8 usually showed the lowest RA values, while C3 exhibited the highest $\mathrm{RA}$ values at 35 dap ( $\mathrm{RA}_{35}$; Figure $2 \mathrm{a}, \mathrm{c}$ and Figure $\left.\mathrm{S} 3 \mathrm{a}\right)$. In agreement with what was found for $\mathrm{RA}_{35}$, the $\mathrm{C} 8$ genotype showed the smallest $\mathrm{SA}$ values at 35 dap $\left(\mathrm{SA}_{35}\right)$ in every season (Figure $2 b$ and Figure $S 3 b$ ), while the $S_{35}$ values for $C 7$ were much higher in Spring than those in Winter or Fall (Figure 2b,d), despite the $\mathrm{RA}_{35}$ in C7 lagging behind in every season (Figure 2a,c). In contrast, the shoot growth and root growth rates of $\mathrm{C} 1$ were similar in every season and normally higher than in the other CHD genotypes studied (Figure S2).

Regarding the GOAK genotypes, the estimated RA exponentially increased between 0 and 35 dap. The highest RA growth was observed in Spring ( $p$-value $=0.000)$, followed by Fall, while in Winter, a slower growth was observed (Figure 3a,c and Figure S4a and Table S3). $\mathrm{RA}_{35}$ was similar in all the genotypes in Fall ( $p$-value $\left.=0.624\right)$, and Spring $(p$-value $=0.321)$, and also slightly significantly different $(p$-value $=0.046)$ in Winter (Figure $3 a$ and Figure S4a). RA growth values were quite similar in all GOAK genotypes, with the extreme values shown by G5 in Winter and G3 in Spring (Figure S2a and Table S3). The highest growth rates of the SA were observed during the Fall (Figure S2b and Table S4), and the $\mathrm{SA}_{35}$ values significantly differed between GOAK genotypes in every season (Figure $3 \mathrm{~b}$ and Figure S4b). Overall, G5 showed significantly higher $\mathrm{SA}_{35}$ values than the G1 and G6 genotypes, but in Spring, only the SA 35 values of G5 were significantly higher than the other GOAK genotypes (Figure 3b,d and Figure S4b).

In the ROAK cultivars, we did not find significant differences in the $\mathrm{RA}_{35}$ values between ROAK genotypes in Winter ( $p$-value $=0.999)$ or Spring ( $p$-value $=0.645$; Figure $4 \mathrm{a}$ and Figure S5a and Table S3). Consistent with the differences observed for $\mathrm{RA}_{35}$ values in Fall (Figure $4 \mathrm{a}$ and Figure S5a), the lowest growth rate of the RA occurred for the R4 and R5 genotypes in this season (Figure S2a and Table S3).

Conversely, the growth rate of SA was much lower during Spring for all the ROAK genotypes (Figure S2b and Table S3), which also showed similar $\mathrm{RA}_{35}$ values in this season (Figure $4 \mathrm{~b}$ and Figure S5b). The R3 and R4 genotypes showed contrasting RA 35 and $\mathrm{SA}_{35}$ values in Fall (Figure 4a,b), while the R5 genotype showed the smallest RA 35 and $\mathrm{SA}_{35}$ values in this season (Figure $4 a, b$ and Figure S5a,b). 

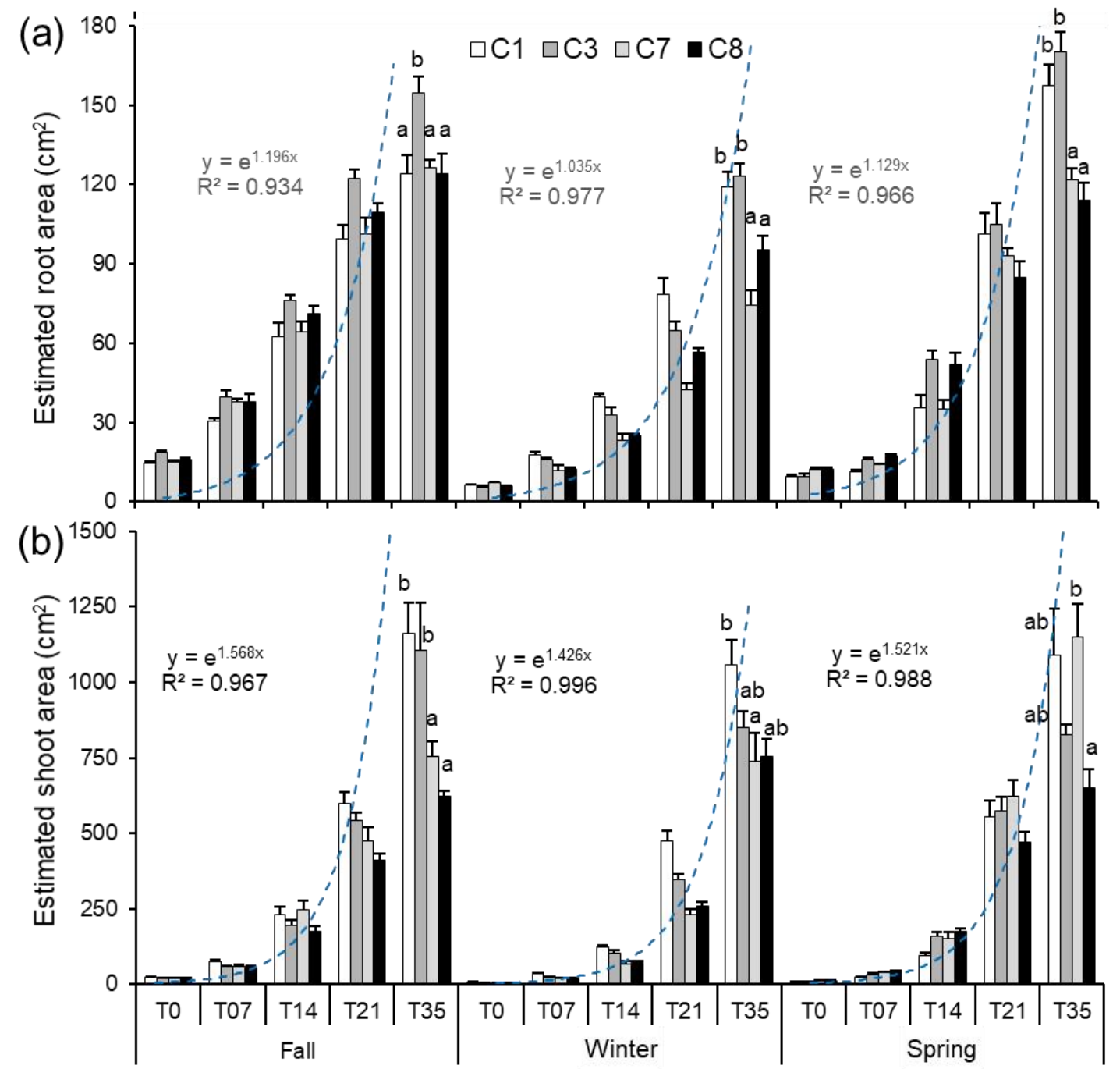

(c)

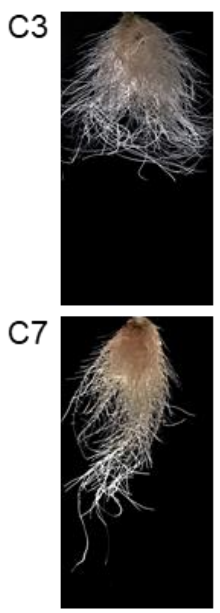

Fall
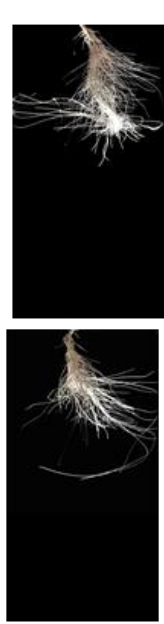

Winter

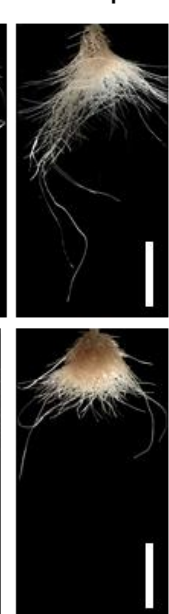

Spring (d)

C3
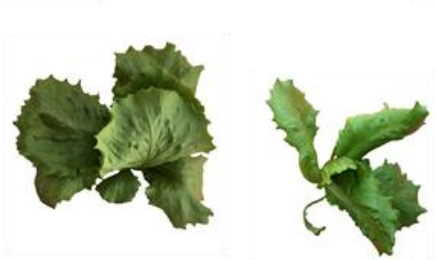

C7
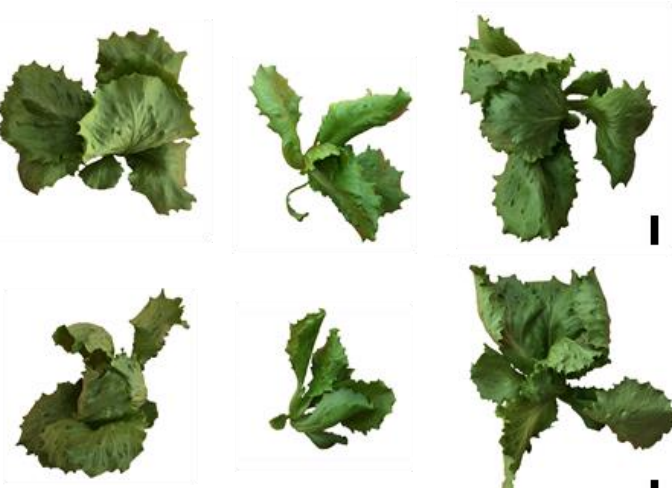

Fall

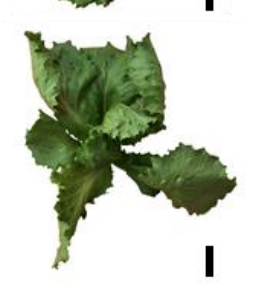

Winter

Spring

Figure 2. Quantitative analysis of root and shoot area in the studied CHD genotypes during hydroponic growth. (a) Average root area $\left(\mathrm{cm}^{2}\right)$ and $(\mathbf{b})$ average shoot area $\left(\mathrm{cm}^{2}\right)$ values in the studied lines $(\mathrm{C} 1, \mathrm{C} 3, \mathrm{C} 7$, and C8) between 0 (T0) and 35 (T35) days after planting (dap). Theoretical exponential growth curves are depicted in blue. Different letters indicate significant differences at 35 dap (LSD; $p$-value < 0.01). (c,d) Representative images of the root (c) and shoot (d) system of C3 and C7 genotypes at 14 and 21 dap, respectively. Scale bars: $50 \mathrm{~mm}$. 

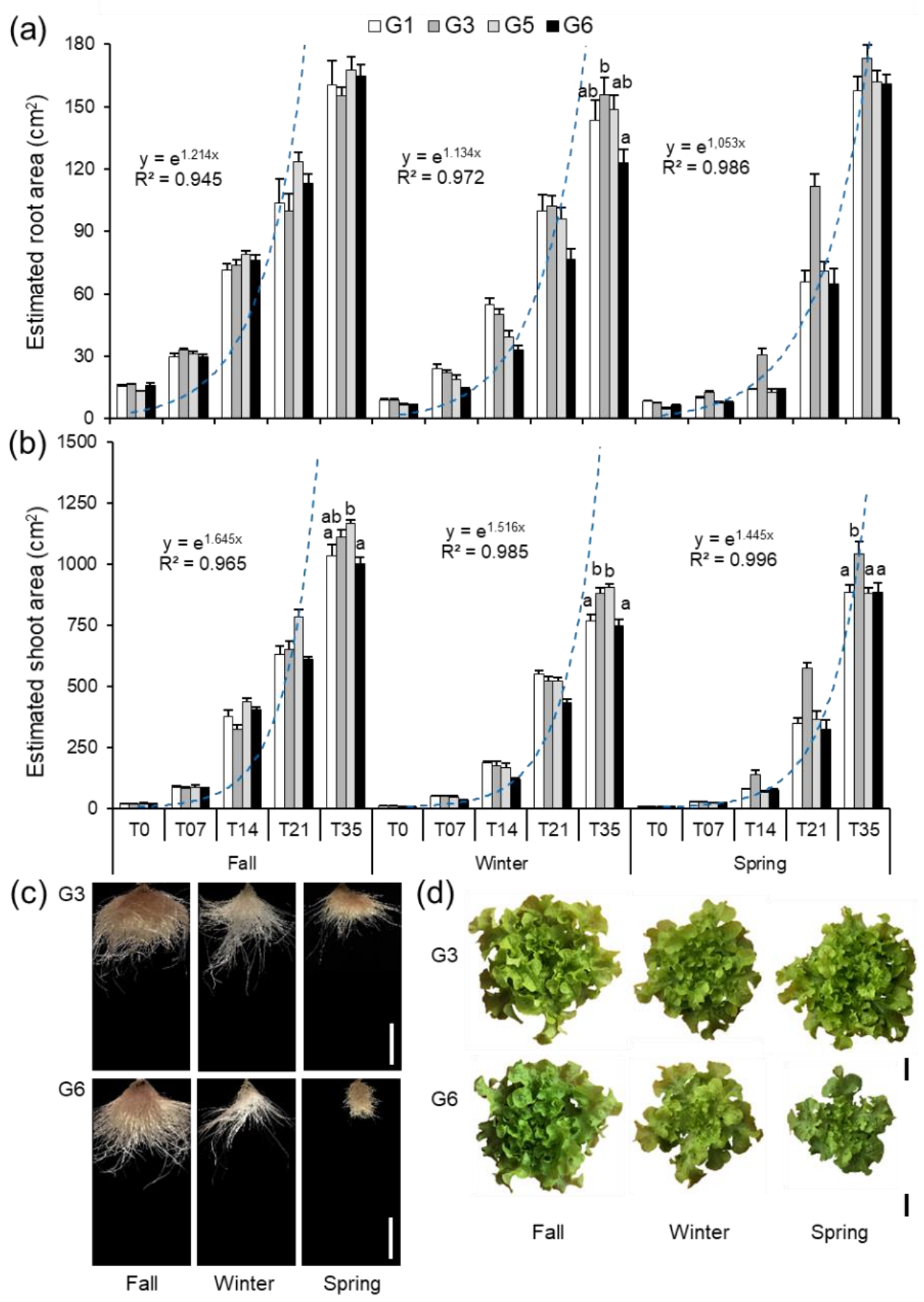

Figure 3. Quantitative analysis of root and shoot area in the studied GOAK genotypes during hydroponic growth. (a) Average root area $\left(\mathrm{cm}^{2}\right)$ and $(\mathbf{b})$ average shoot area $\left(\mathrm{cm}^{2}\right)$ values in the studied lines (G1, G3, G5, and G6) between 0 (T0) and 35 (T35) dap. Theoretical exponential growth curves are depicted in blue. Different letters indicate significant differences at 35 dap (LSD; $p$-value < 0.01). (c,d) Representative images of the root (c) and shoot (d) system of G3 and G6 genotypes at 14 and 21 dap, respectively. Scale bars: $50 \mathrm{~mm}$. 

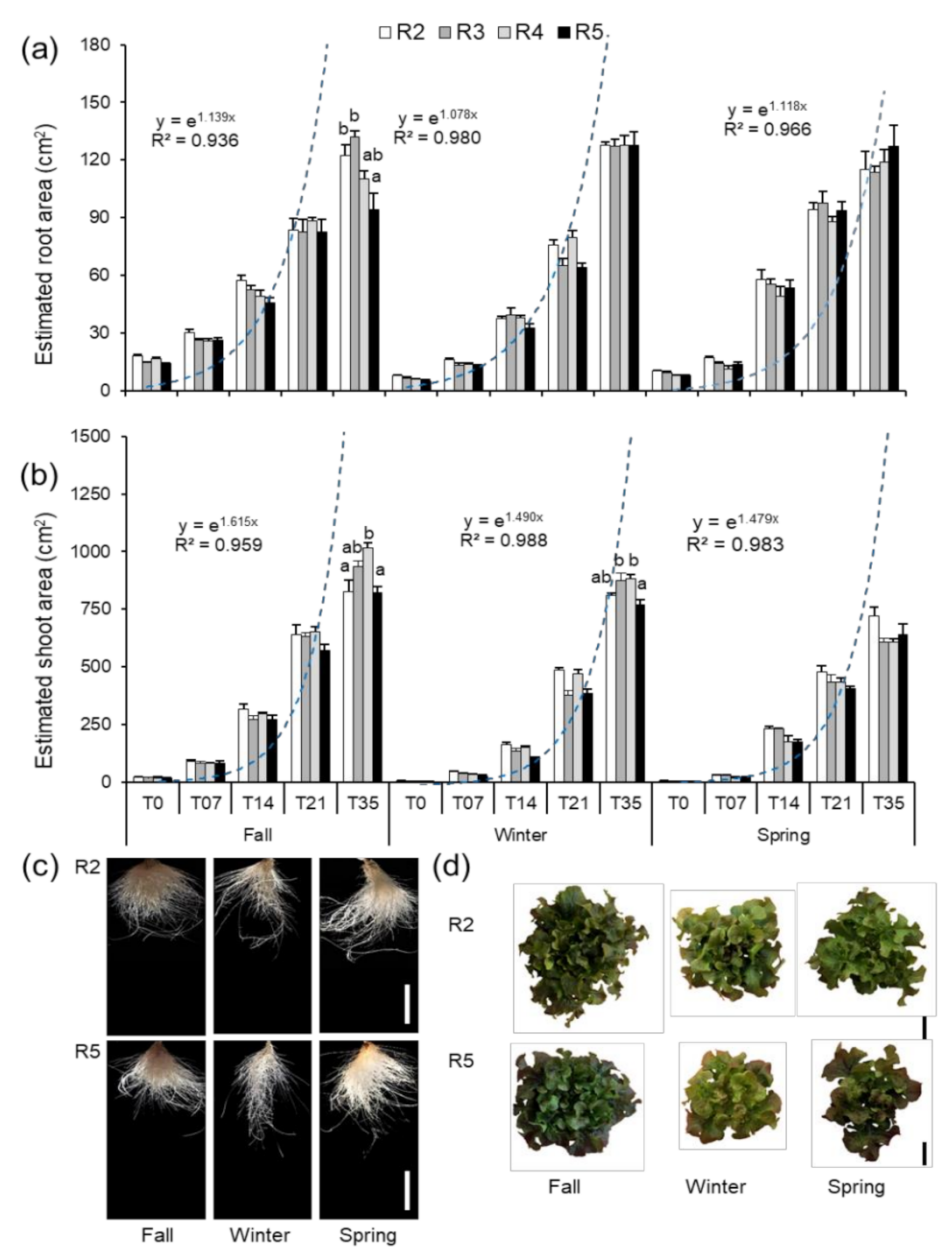

Figure 4. Quantitative analysis of root and shoot area in the studied ROAK genotypes during hydroponic growth. (a) Average root area $\left(\mathrm{cm}^{2}\right)$ and $(\mathbf{b})$ average shoot area $\left(\mathrm{cm}^{2}\right)$ values in the studied lines (R2, R3, R4 and R5) between 0 (T0) and 35 (T35) dap. Theoretical exponential growth curves are depicted in blue. Different letters indicate significant differences between genotypes at 35 dap (LSD; $p$-value < 0.01). (c,d) Representative images of the root (c) and shoot (d) system of R2 and R5 genotypes at 14 and 21 dap, respectively. Scale bars: $50 \mathrm{~mm}$.

\subsection{Variations in Root and Shoot Weights in the Studied Lettuce Cultivars}

We measured several growth-related traits of the root and the shoot system at 45 dap (see Materials and Methods; Table S4 and Figure S6a). Root FW and shoot FW were found to be dependent on the cultivar type $(p$-value $=0.000)$ and the growing season $(p$-value $=0.002)$. The GOAK genotypes had significantly heavier root systems $(\mathrm{FW}=33.50 \pm 0.94 \mathrm{~g}$; $\mathrm{DW}=1.39 \pm 0.05 \mathrm{~g} ; n=57)$ than those from ROAK $(\mathrm{FW}=24.20 \pm 0.58 \mathrm{~g} ; \mathrm{DW}=1.19 \pm 0.05 \mathrm{~g}$; $n=59)$ or $\mathrm{CHD}(\mathrm{FW}=24.60 \pm 0.85 \mathrm{~g} ; \mathrm{DW}=1.26 \pm 0.06 \mathrm{~g} ; n=60)$, being the largest in Spring for GOAK and CHD (Figure S6b). As for the CHD genotypes, C1 had significantly $(p$-value $<0.01)$ heavier root systems $(\mathrm{FW}=28.60 \pm 1.80 \mathrm{~g} ; \mathrm{DW}=1.63 \pm 0.26 \mathrm{~g}$; $n=15)$ than $\mathrm{C} 8(\mathrm{FW}=21.10 \pm 1.02 \mathrm{~g} ; \mathrm{DW}=0.97 \pm 0.07 \mathrm{~g} ; n=15$; Figure 5a). Among the eight L. sativa var. crispa genotypes studied, G3 showed the heaviest root system $(\mathrm{FW}=41.20 \pm 2.03 \mathrm{~g} ; \mathrm{DW}=1.56 \pm 0.05 \mathrm{~g} ; n=14)$, while the R5 root system was the lightest one $(\mathrm{FW}=21.00 \pm 1.07 \mathrm{~g} ; \mathrm{DW}=0.96 \pm 0.08 \mathrm{~g} ; n=14$; Figure $5 \mathrm{a})$. Despite the FW and DW values being highly correlated overall (Figure S6b), the root DW values were significantly $(p$-value $=0.000)$ higher in Winter $(1.56 \pm 0.06 \mathrm{~g} ; n=59)$, with the lowest values found in Fall $(1.00 \pm 0.34 \mathrm{~g} ; n=60)$, but these were not strongly dependent $(p$-value $=0.014)$ on the type of cultivar (CHD, GOAK or ROAK). 
(a)

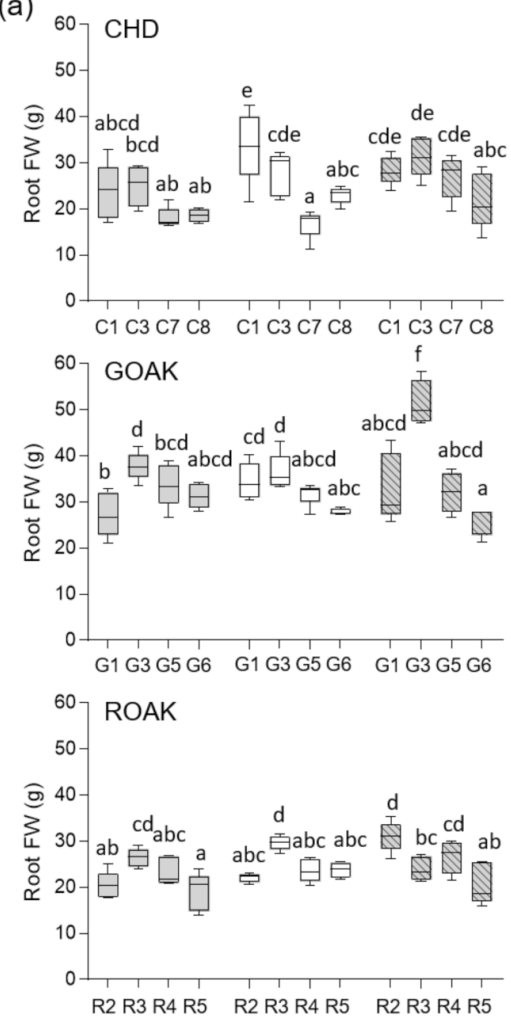

(b)
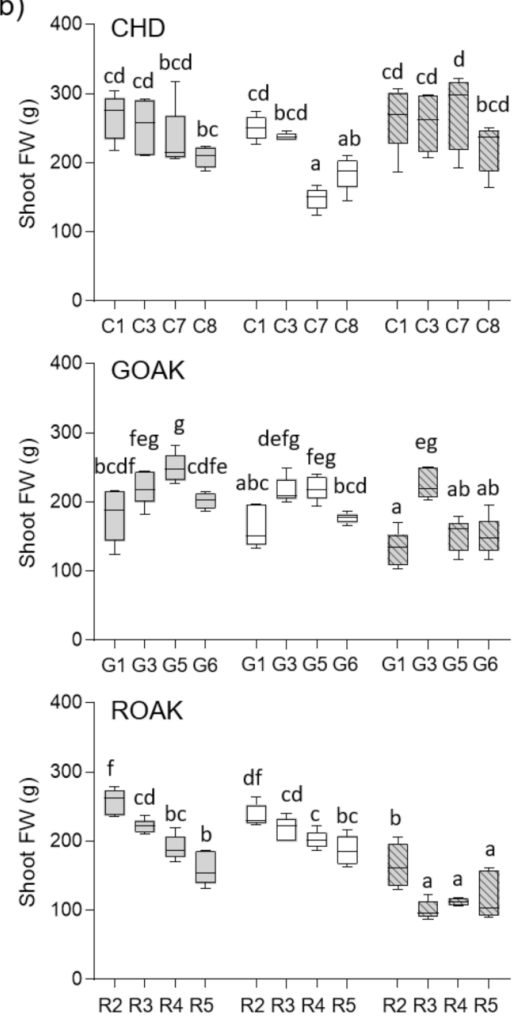

Figure 5. Fresh weight of the studied genotypes at the end of the experiment. (a) Root FW and (b) shoot FW (Fall, grey-filled bars; Winter, white-filled bars; Spring, lined-filled bars). Different letters indicate significant $(p$-value $<0.01$ ) differences between CHD, GOAK and ROAK samples.

Despite their small root systems, shoot weights were significantly $(p$-value $=0.000)$ higher in the CHD genotypes $(\mathrm{FW}=233.30 \pm 6.18 \mathrm{~g}$; DW $=8.84 \pm 0.30 \mathrm{~g} ; n=59)$ than those in GOAK $(\mathrm{FW}=190.90 \pm 5.36 \mathrm{~g}$; $\mathrm{DW}=7.81 \pm 0.25 \mathrm{~g} ; n=60)$ or ROAK (FW $=182.10 \pm 6.72 \mathrm{~g} ; \mathrm{DW}=7.71 \pm 0.19 \mathrm{~g} ; n=59)$, even though the CHD shoots had significantly $(p$-value $=0.000)$ less leaves $(15.90 \pm 0.50 ; n=20)$ than GOAK shoots $(29.80 \pm 0.64$; $n=60)$ or ROAK $(28.40 \pm 0.42 ; n=60)$ shoots (Table S4). Remarkably, a statistically significant ( $p$-value $=0.000) \mathrm{G} \times$ E interaction affected shoot FW in GOAK and ROAK genotypes. The shoot FW values from G3 and R2 were much higher than other GOAK or ROAK genotypes only in Spring (Figure $5 b$ ). The shoot DW values were also significantly ( $p$-value $=0.000)$ higher in Winter $(9.27 \pm 0.26 \mathrm{~g} ; n=59)$, but surprisingly, the lowest shoot DW values were found in Spring $(7.00 \pm 0.21 \mathrm{~g} ; n=59)$. The root-to-shoot ratio (R:S ratio) steadily increased from Fall to Spring in the CHD and ROAK cultivars, while non-significant differences were found for the R:S ratio of GOAK in Winter and Spring (Figure S6c).

Root water content (RWC) varied from $94.50 \pm 0.36 \%$ in $\mathrm{C} 1$ to $96.10 \pm 0.20 \%$ in G3, with a clear effect of the growing season, with lower RWC values in Winter and higher RWC values in Fall (Table S4). Also, shoot water content (SWC) was significantly $(p$-value $=0.001)$ lower in ROAK cultivars $(95.50 \pm 0.15 \% ; n=57)$, with the highest values found in C8 $(96.50 \pm 0.21 \% ; n=15)$. Intriguingly, water content (both in the shoot and in the root) was negatively and significantly $(p$-value $=0.000)$ correlated with root DW and most considerably in Winter (Figure S6d).

\subsection{Tipburn Severity during Hydroponic Growth}

Tipburn was scored weekly on cultivars grown in hydroponic culture by means of a visual scaling rate (Figure S1), and it was found that the symptoms steadily increased from 3-4 weeks after planting onwards (Table S5). We found a significant $\mathrm{G} \times \mathrm{E}$ interaction 
for tipburn severity in the CHD genotypes ( $p$-value $=0.000)$, with a higher contribution of the Fall and Spring seasons on the scores at 45 dap (Figure 6a and Table S5). While C3 showed higher scores in every season $(6.3 \pm 0.5 ; n=18)$, others only showed tipburn symptoms during Spring (C8) or Fall (C7 and C1). Additionally, tipburn phenotypes were highly variable within individual plants in $\mathrm{C} 1, \mathrm{C} 3$, and $\mathrm{C} 8$ (Table S5), as estimated by their variance values at 45 dap $(7.22 ; n=54)$ compared with those of C7 $(2.24 ; n=18)$. The tipburn severity in the ROAK genotypes (measured at 45 dap) was not dependent on the growing season ( $p$-value $=0.296$ ), but a significant dependency on the genotype was observed $(p$-value $=0.000)$, with R2 leaves showing similar tipburn symptoms and much higher scores $(8.0 \pm 0.9 ; n=18)$ than those of the other ROAK genotypes studied $(2.1 \pm 1.5$; $n=54)$. On the other hand, tipburn symptoms of the GOAK leaves were dependent on the growing season and the genotype $(p$-value $=0.041)$, with higher scores in Spring for G3 and G6 $(5.0 \pm 2.4 ; n=16)$ as compared with the other GOAK genotypes studied $(1.8 \pm 1.2$; $n=56)$.

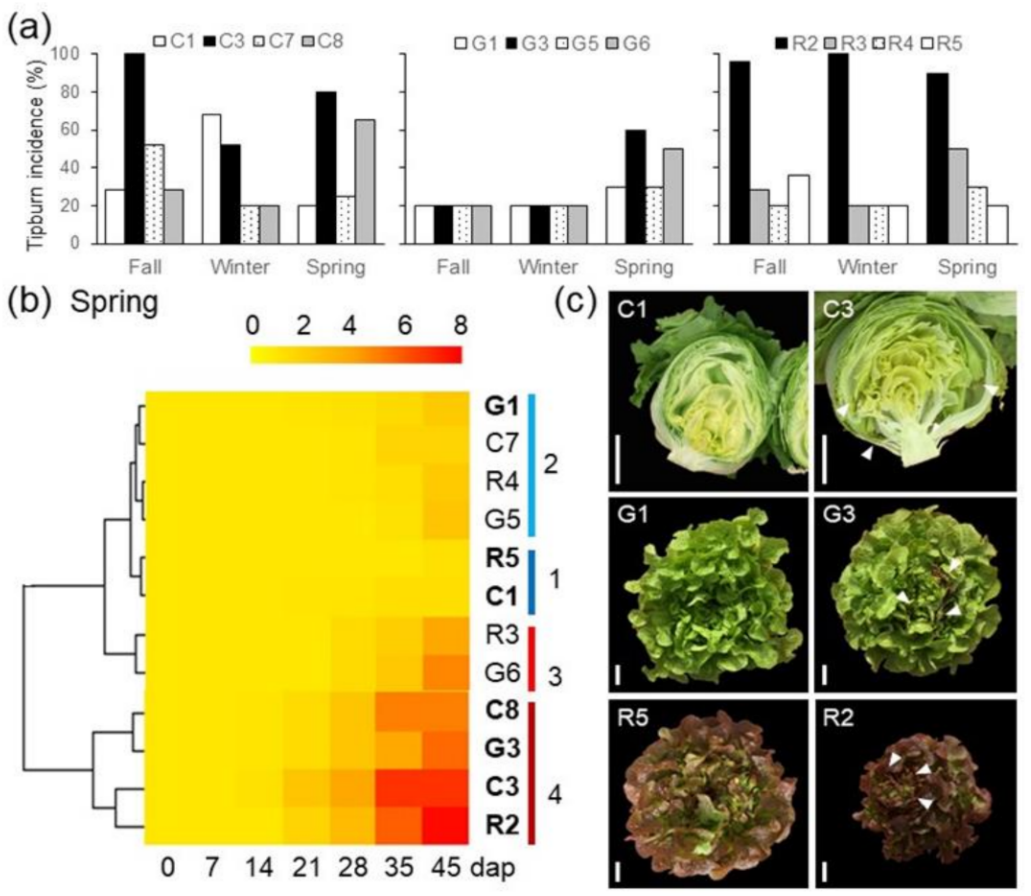

Figure 6. Tip-burn assessment in the studied genotypes. (a) Tipburn incidence of the studied genotypes at 45 days after planting (dap) (b) Heatmap of tipburn scoring values during the Spring season. Colored bars indicate the severity of the tipburn phenotypes in the studied genotypes, from highly tolerant $(0$, yellow) to highly sensitive $(8, \mathrm{red})$. Genotypes were grouped into four groups (tolerant: 1,2; sensitive: 3,4). (c) Representative images of rosettes of genotypes with extreme tipburn phenotypes (tolerant, left panels; sensitive: right panels) at 45 dap. White arrowheads point to regions where tipburn lesions are present. Scale bars: $50 \mathrm{~mm}$.

Next, we classified the studied genotypes based on their tipburn severity symptoms during the Spring season into four groups: (i) highly tolerant (R5, C1), (ii) intermediate (C7, R4, G1, G5), (iii) sensitive (R3, G6), and (iv) highly sensitive (C8, G3, R2, C3) (Figure 6b). Some highly sensitive genotypes, such as R2 or C3, obtained higher scores in all the seasons, while others, such as C8, G3, or G6 only showed tipburn symptoms during the Spring season (Table S5). Representative pictures of some of the most tolerant and most sensitive genotypes for tipburn symptoms are shown in Figure 6c.

\subsection{Leaf Nutrient Variation in the Spring Season in the Studied Lettuce Cultivars}

We determined nutrient concentration in mature, intermediate, and juvenile leaves of the studied genotypes in the Spring season at the end of the experiment (Table S6). For 
the studied nutrients, most of the variation was found associated with leaf type ( $p$-value between $0.0000(\mathrm{Ca}, \mathrm{P}, \mathrm{Mg}, \mathrm{Na}, \mathrm{Fe}, \mathrm{Mn}$, and $\mathrm{Cu})$ and $0.0078(\mathrm{~K})$ ) or cultivar type (p-value between $0.0000(\mathrm{~K}, \mathrm{P}, \mathrm{S}, \mathrm{Mg}, \mathrm{Na}, \mathrm{Fe}, \mathrm{Mn}$, and $\mathrm{Cu}$ ) and 0.0029 (Zn)) (Tables 2 and 3). In the CHD cultivar, we found the lowest nutrient levels, while in the GOAK cultivars, their nutrient levels were significantly higher. Nutrient concentrations in the ROAK cultivar were intermediate and similar to GOAK, except for $\mathrm{P}$, where the highest values were observed (Table 2). In regard to the studied macronutrients (K, Ca, P, S, Mg, and $\mathrm{Na}$ ), all cultivars showed higher $\mathrm{P}$ levels in the juvenile leaves, while the $\mathrm{Ca}, \mathrm{Mg}$, and $\mathrm{Na}$ levels were higher in the mature leaves, albeit not significant for $\mathrm{Mg}$ or $\mathrm{Na}$ in $\mathrm{CHD}$ (Table 2). $\mathrm{K}$ levels were significantly higher in mature leaves in the GOAK and ROAK cultivars than in intermediate or juvenile leaves; $S$ showed similar behavior in the CHD and ROAK cultivars with higher concentrations in the juvenile leaves than the GOAK cultivar but without significant differences (Table 2). For the studied micronutrients ( $\mathrm{Fe}, \mathrm{Mn}, \mathrm{Zn}$, and $\mathrm{Cu}$ ), we found significantly higher concentrations of $\mathrm{Mn}$ and $\mathrm{Cu}$ in mature leaves of all the cultivars. On the other hand, Fe was significantly higher in mature leaves in GOAK and ROAK, and Zn showed a contrasting behavior in these two cultivars, with significantly higher levels in juvenile leaves in ROAK (Table 2). We next analyzed the mature-to-juvenile $(\mathrm{M} / \mathrm{J})$ ratio and found higher values of $\mathrm{Ca}, \mathrm{Na}$, and $\mathrm{Mn}$ in mature leaves irrespectively of the cultivar. Interestingly, the CHD cultivar showed low $(\leq 1) \mathrm{M} / \mathrm{J}$ ratios of $\mathrm{K}, \mathrm{S}, \mathrm{Mg}$, Fe, $\mathrm{Zn}$, and $\mathrm{Cu}$ as compared to those in the GOAK and ROAK cultivars (Tables 2 and 3).

Considering the nutrient concentration of all leaves, we found significant differences between the studied genotypes (Table 4). Overall, the CHD genotypes contained a lower nutrient concentration than the ROAK and GOAK genotypes (Table 4). G3 and R4 had the highest nutrient concentration, which almost doubled those found in C1 and C7 (Table 4). We did not find a clear association between total nutrient concentration and tipburn scores (Figure 6a,b).

After analyzing each nutrient individually, we found that all three cultivars showed similar trends for macronutrient $(\mathrm{K}>\mathrm{Ca}>\mathrm{P}>\mathrm{S}>\mathrm{Mg}>\mathrm{Na})$ and micronutrient $(\mathrm{Fe}>\mathrm{Mn}>\mathrm{Zn}>\mathrm{Cu})$ concentrations (see percentage in italics in Tables 5 and 6). However, some genotypes displayed substantial differences in the amounts of specific nutrients compared with those in other genotypes of the same cultivar. As regards the CHD genotypes, $\mathrm{C} 1$ and $\mathrm{C} 7$ had higher concentrations or percentages for all the nutrients analyzed except for $\mathrm{Mn}, \mathrm{Zn}$, and $\mathrm{Cu}$, where $\mathrm{C} 1$ showed the highest percentages. Comparing the most differentiated genotypes (C1 and C7 vs. C3 and C8), we observed significant differences in $\mathrm{K}(p$-value $=0.0003), \mathrm{Ca}$ $(p$-value $=0.0047), \mathrm{S}(p$-value $=0.0026), \mathrm{Mg}(p$-value $=0.0070), \mathrm{Na}(p$-value $=0.0024)$, and $\mathrm{Mn}$ $(p$-value $=0.0025)$. We classified the CHD genotypes based on their statistically significant nutrient levels, as follows: $\mathrm{C} 1>\mathrm{C} 7>\mathrm{C} 8=\mathrm{C} 3$ (Tables 5 and 6). In relation to the GOAK genotypes, G3 contained higher levels of most nutrients compared to those found in G5, G1, and G6 (Tables 5 and 6). Conversely, G6 showed lower levels of some macronutrients $(\mathrm{K}, \mathrm{P}, \mathrm{S}, \mathrm{Mg}$, and $\mathrm{Na})$, being the most malnourished GOAK genotype but without showing significant differences with respect to G1 to G5, which were nutritionally more balanced (Table 5). We found a significantly ( $p$-value $=0.0004$ ) higher nutrient concentration in G3 as compared to those in G5, G1, and G6. We ordered the GOAK genotypes as regards to their statistically significant nutrient levels, as follows: G3 > G1 > G5 > G6 Table 6). We did not find significant differences between the ROAK genotypes in regards to total macronutrient and micronutrient content $(p$-value $=0.0650)$. However, we observed significant differences between R4 and the other ROAK genotypes for $\mathrm{P}(p$-value $=0.0021)$ and $\mathrm{S}$ $(p$-value $=0.0040)$, which resulted in sorting the ROAK genotypes based on significant $\mathrm{P}$ and $\mathrm{S}$ nutrient concentrations from R4 $>$ R5 $>$ R2 $>$ R3 (Tables 5 and 6). Tipburn incidence and tipburn scores (Figure 6a,b) associated with the R2 and R3 genotypes containing lower $\mathrm{P}$ and $\mathrm{S}$ content (Table 5). 


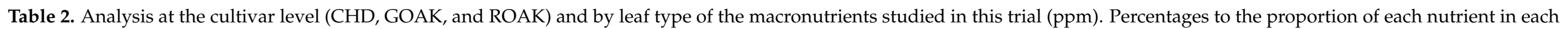

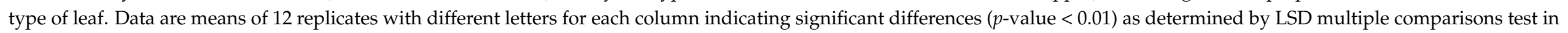
different types of leaves analyzed.

\begin{tabular}{|c|c|c|c|c|c|c|c|c|c|c|c|c|c|c|c|c|c|c|}
\hline \multirow[b]{2}{*}{$\begin{array}{l}\text { Leaf } \\
\text { Type }\end{array}$} & \multicolumn{6}{|c|}{ CHD } & \multicolumn{6}{|c|}{ GOAK } & \multicolumn{6}{|c|}{ ROAK } \\
\hline & K & $\mathrm{Ca}$ & $\mathbf{P}$ & $\mathrm{s}$ & Mg & $\mathrm{Na}$ & K & $\mathrm{Ca}$ & $\mathbf{P}$ & $\mathrm{s}$ & Mg & $\mathrm{Na}$ & K & $\mathrm{Ca}$ & $\mathbf{P}$ & $\mathrm{s}$ & $\mathrm{Mg}$ & $\mathrm{Na}$ \\
\hline Mature & $\begin{array}{c}1349.00 \mathrm{a} \\
67.52 \%\end{array}$ & $\begin{array}{c}340.68 \mathrm{~b} \\
17.05 \%\end{array}$ & $\begin{array}{c}92.26 \mathrm{a} \\
4.62 \%\end{array}$ & $\begin{array}{c}101.45 \mathrm{~b} \\
5.08 \%\end{array}$ & $\begin{array}{l}65.91 \mathrm{a} \\
3.30 \%\end{array}$ & $\begin{array}{c}38.02 \mathrm{~b} \\
1.90 \%\end{array}$ & $\begin{array}{c}3290.63 \mathrm{~b} \\
66.49 \%\end{array}$ & $\begin{array}{c}794.50 \mathrm{~b} \\
16.05 \%\end{array}$ & $\begin{array}{c}228.85 \mathrm{a} \\
4.62 \%\end{array}$ & $\begin{array}{c}309.97 \mathrm{~b} \\
6.26 \%\end{array}$ & $\begin{array}{c}185.36 \mathrm{~b} \\
3.75 \%\end{array}$ & $\begin{array}{c}109.80 \mathrm{~b} \\
2.22 \%\end{array}$ & $\begin{array}{c}3204.74 \mathrm{~b} \\
69.85 \%\end{array}$ & $\begin{array}{c}608.37 \mathrm{~b} \\
13.26 \%\end{array}$ & $\begin{array}{c}272.64 \mathrm{a} \\
5.94 \%\end{array}$ & $\begin{array}{c}179.97 \mathrm{ab} \\
3.92 \%\end{array}$ & $\begin{array}{c}184.19 \mathrm{~b} \\
4.01 \%\end{array}$ & $\begin{array}{c}115.74 \mathrm{c} \\
2.52 \%\end{array}$ \\
\hline Juvenile & $\begin{array}{c}1657.43 \text { a } \\
73.72 \%\end{array}$ & $\begin{array}{c}155.36 \mathrm{a} \\
6.91 \%\end{array}$ & $\begin{array}{c}218.00 \mathrm{c} \\
9.70 \%\end{array}$ & $\begin{array}{c}121.04 \mathrm{~b} \\
5.38 \%\end{array}$ & $\begin{array}{c}64.44 \mathrm{a} \\
2.87 \%\end{array}$ & $\begin{array}{c}22.90 \mathrm{a} \\
1.02 \%\end{array}$ & $\begin{array}{c}2415.40 \\
\mathrm{ab} \\
72.69 \% \\
\end{array}$ & $\begin{array}{c}227.05 \mathrm{a} \\
6.83 \%\end{array}$ & $\begin{array}{c}326.71 \mathrm{~b} \\
9.83 \%\end{array}$ & $\begin{array}{c}199.86 \text { a } \\
6.01 \%\end{array}$ & $\begin{array}{c}111.22 \mathrm{a} \\
3.35 \%\end{array}$ & $\begin{array}{c}28.52 \mathrm{a} \\
0.86 \%\end{array}$ & $\begin{array}{c}2424.82 \mathrm{a} \\
72.62 \% \\
\end{array}$ & $\begin{array}{c}141.51 \mathrm{a} \\
4.24 \%\end{array}$ & $\begin{array}{c}440.74 \mathrm{~b} \\
13.20 \%\end{array}$ & $\begin{array}{c}192.42 \mathrm{~b} \\
5.76 \%\end{array}$ & $\begin{array}{c}104.57 \text { a } \\
3.13 \%\end{array}$ & $\begin{array}{l}23.21 \mathrm{a} \\
0.69 \%\end{array}$ \\
\hline$p$-value & 0.1711 & 0.0001 & 0.0000 & 0.1196 & 0.4857 & 0.0211 & 0.0609 & 0.0001 & 0.0159 & 0.0164 & 0.0133 & 0.0001 & 0.0373 & 0.0000 & 0.0012 & 0.0332 & 0.0000 & 0.0000 \\
\hline $\begin{array}{l}\mathrm{M} / \mathrm{J} \\
\text { ratio }\end{array}$ & 0.81 & 2.19 & 0.42 & 0.84 & 1.02 & 1.66 & 1.36 & 3.50 & 0.70 & 1.55 & 1.67 & 3.85 & 1.32 & 4.30 & 0.62 & 1.02 & 1.76 & 4.99 \\
\hline
\end{tabular}

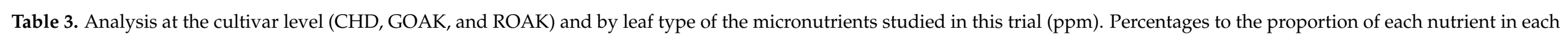

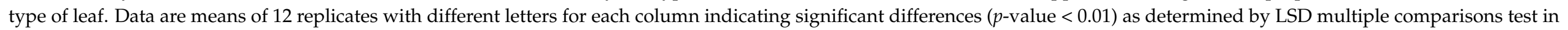
different types of leaves analyzed.

\begin{tabular}{|c|c|c|c|c|c|c|c|c|c|c|c|c|}
\hline \multirow[b]{2}{*}{ Leaf Type } & \multicolumn{4}{|c|}{ CHD } & \multicolumn{4}{|c|}{ GOAK } & \multicolumn{4}{|c|}{ ROAK } \\
\hline & $\mathrm{Fe}$ & Mn & $\mathrm{Zn}$ & $\mathrm{Cu}$ & $\mathrm{Fe}$ & Mn & $\mathrm{Zn}$ & $\mathrm{Cu}$ & $\mathrm{Fe}$ & Mn & $\mathrm{Zn}$ & $\mathrm{Cu}$ \\
\hline \multirow{2}{*}{ Mature } & $4.92 \mathrm{a}$ & $3.90 \mathrm{~b}$ & $1.67 \mathrm{ab}$ & $0.23 \mathrm{~b}$ & $16.72 \mathrm{~b}$ & $8.89 \mathrm{~b}$ & $3.35 \mathrm{~b}$ & $0.61 \mathrm{~b}$ & $13.57 \mathrm{~b}$ & $6.75 \mathrm{~b}$ & $1.54 \mathrm{a}$ & $0.37 \mathrm{~b}$ \\
\hline & $0.25 \%$ & $0.20 \%$ & $0.08 \%$ & $0.01 \%$ & $0.34 \%$ & $0.18 \%$ & $0.07 \%$ & $0.01 \%$ & $0.30 \%$ & $0.15 \%$ & $0.03 \%$ & $0.01 \%$ \\
\hline \multirow{2}{*}{ Intermediate } & $4.12 \mathrm{a}$ & $1.99 \mathrm{a}$ & $1.17 \mathrm{a}$ & $0.13 \mathrm{a}$ & $8.37 \mathrm{a}$ & $3.61 \mathrm{a}$ & $1.67 \mathrm{a}$ & $0.28 \mathrm{a}$ & $6.01 \mathrm{a}$ & $2.45 \mathrm{a}$ & $1.28 \mathrm{a}$ & $0.12 \mathrm{a}$ \\
\hline & $0.21 \%$ & $0.10 \%$ & $0.06 \%$ & $0.01 \%$ & $0.27 \%$ & $0.12 \%$ & $0.05 \%$ & $0.01 \%$ & $0.19 \%$ & $0.08 \%$ & $0.04 \%$ & $0.00 \%$ \\
\hline \multirow{2}{*}{ Juvenile } & $5.23 \mathrm{a}$ & $1.85 \mathrm{a}$ & $1.93 \mathrm{~b}$ & $0.21 \mathrm{~b}$ & $8.58 \mathrm{a}$ & $3.00 \mathrm{a}$ & $2.35 \mathrm{ab}$ & $0.30 \mathrm{a}$ & $6.92 \mathrm{a}$ & $2.04 \mathrm{a}$ & $2.50 \mathrm{~b}$ & $0.19 \mathrm{a}$ \\
\hline & $0.23 \%$ & $0.08 \%$ & $0.09 \%$ & $0.01 \%$ & $0.26 \%$ & $0.12 \%$ & $0.09 \%$ & $0.01 \%$ & $0.21 \%$ & $0.06 \%$ & $0.07 \%$ & $0.01 \%$ \\
\hline $\mathrm{M} / \mathrm{J}$ ratio & 0.94 & 2.11 & 0.87 & 1.09 & 1.95 & 2.96 & 1.43 & 2.03 & 1.96 & 3.31 & 0.62 & 1.95 \\
\hline
\end{tabular}




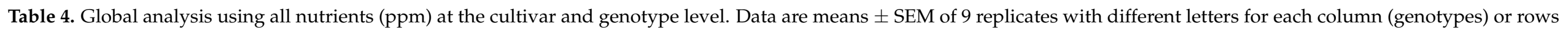
(cultivars) indicating significant differences $(p$-value $<0.01$ ) as determined by LSD multiple comparisons test.

\begin{tabular}{|c|c|c|c|c|c|}
\hline $\mathrm{C} 1$ & $7670.09 \pm 634.81 \mathrm{~b}$ & G1 & $10,310.58 \pm 338.97 \mathrm{a}$ & $\mathrm{R} 2$ & $10,446.25 \pm 804.42 \mathrm{a}$ \\
\hline $\mathrm{C} 3$ & $5222.15 \pm 182.30 \mathrm{a}$ & G3 & $15,708.86 \pm 1099.30 b$ & R3 & $10,015.28 \pm 1445.66 \mathrm{a}$ \\
\hline $\mathrm{C} 7$ & $6833.17 \pm 294.16 b$ & G5 & $10,011.790 \pm 990.28 \mathrm{a}$ & $\mathrm{R} 4$ & $13,405.84 \pm 1389.01 \mathrm{a}$ \\
\hline $\mathrm{C} 8$ & $4966.47 \pm 392.13 \mathrm{a}$ & G6 & $9424.43 \pm 1482.28 \mathrm{a}$ & R5 & $9924.48 \pm 661.77 \mathrm{a}$ \\
\hline $\mathrm{p}$-value & 0.0004 & & 0.0004 & & 0.0650 \\
\hline Average & $6172.97 \pm 381.09 a$ & & $11,363.91 \pm 886.52 b$ & & $11,091.40 \pm 691.06 \mathrm{~b}$ \\
\hline
\end{tabular}

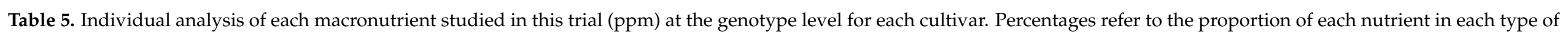

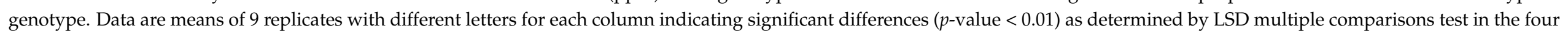
genotypes analyzed per cultivar ( $p$-value).

\begin{tabular}{|c|c|c|c|c|c|c|c|c|c|c|c|c|c|c|c|c|c|c|c|c|}
\hline CHD & $\mathrm{K}$ & $\mathrm{Ca}$ & $P$ & $S$ & $\mathrm{Mg}$ & $\mathrm{Na}$ & GOAK & K & $\mathrm{Ca}$ & $P$ & $\mathrm{~S}$ & $\mathrm{Mg}$ & $\mathrm{Na}$ & ROAK & $\mathrm{K}$ & $\mathrm{Ca}$ & $\mathbf{P}$ & $S$ & $\mathrm{Mg}$ & $\mathrm{Na}$ \\
\hline C1 & $\begin{array}{c}5493.20 \\
\text { b } \\
71.62 \%\end{array}$ & $\begin{array}{c}918.54 \\
\text { b } \\
11.98 \%\end{array}$ & $\begin{array}{c}468.06 \\
b \\
6.10 \%\end{array}$ & $\begin{array}{c}390.30 \\
\mathrm{~b} \\
5.09 \%\end{array}$ & $\begin{array}{c}237.80 \\
\text { b } \\
3.10 \%\end{array}$ & $\begin{array}{c}128.51 \\
c \\
1.68 \%\end{array}$ & G1 & $\begin{array}{c}7171.16 \\
\text { a } \\
69.55 \%\end{array}$ & $\begin{array}{c}1310.47 \\
\mathrm{a} \\
13.05 \%\end{array}$ & $\begin{array}{c}655.84 \\
\mathrm{~b} \\
6.53 \%\end{array}$ & $\begin{array}{c}614.46 \\
a \\
6.12 \%\end{array}$ & $\begin{array}{c}339.65 \\
a \\
3.38 \%\end{array}$ & $\begin{array}{c}170.41 \\
\mathrm{~b} \\
1.70 \%\end{array}$ & R2 & $\begin{array}{c}7649.10 \\
\text { a } \\
73.22 \%\end{array}$ & $\begin{array}{c}917.81 \\
\mathrm{ab} \\
8.79 \%\end{array}$ & $\begin{array}{c}726.56 \\
a \\
6.96 \%\end{array}$ & $\begin{array}{c}559.32 \\
\text { b } \\
5.35 \%\end{array}$ & $\begin{array}{c}396.68 \\
a \\
3.80 \%\end{array}$ & $\begin{array}{c}145.85 \\
\mathrm{a} \\
1.40 \%\end{array}$ \\
\hline $\mathrm{C} 7$ & $\begin{array}{c}4849.21 \\
\text { b } \\
70.97 \%\end{array}$ & $\begin{array}{c}755.94 \\
\text { b } \\
11.06 \%\end{array}$ & $\begin{array}{c}549.96 \\
\text { b } \\
8.05 \%\end{array}$ & $\begin{array}{c}355.06 \\
\mathrm{~b} \\
5.20 \%\end{array}$ & $\begin{array}{c}193.96 \\
\text { b } \\
2.84 \%\end{array}$ & $\begin{array}{c}99.52 \\
b c \\
1.46 \%\end{array}$ & G5 & $\begin{array}{c}7094.33 \\
\mathrm{a} \\
70.86 \%\end{array}$ & $\begin{array}{c}902.42 \\
\mathrm{a} \\
9.01 \%\end{array}$ & $\begin{array}{c}858.71 \\
\text { b } \\
8.58 \%\end{array}$ & $\begin{array}{c}628.49 \\
a \\
6.28 \%\end{array}$ & $\begin{array}{c}339.99 \\
\mathrm{a} \\
3.40 \%\end{array}$ & $\begin{array}{c}140.02 \\
\mathrm{a} \\
1.40 \%\end{array}$ & $\mathrm{R} 4$ & $\begin{array}{c}9485.96 \\
\mathrm{a} \\
70.76 \%\end{array}$ & $\begin{array}{l}1253.07 \mathrm{~b} \\
9.35 \%\end{array}$ & $\begin{array}{c}1267.85 \\
c \\
9.46 \%\end{array}$ & $\begin{array}{c}622.57 \\
\mathrm{~b} \\
4.64 \%\end{array}$ & $\begin{array}{c}441.41 \\
\mathrm{a} \\
3.29 \%\end{array}$ & $\begin{array}{c}289.24 \\
\text { b } \\
2.16 \%\end{array}$ \\
\hline C8 & $\begin{array}{c}3480.33 \\
\mathrm{a} \\
70.08 \%\end{array}$ & $\begin{array}{c}573.01 \\
\text { a } \\
11.54 \%\end{array}$ & $\begin{array}{c}409.62 \\
\mathrm{a} \\
8.25 \%\end{array}$ & $\begin{array}{c}247.21 \\
\mathrm{a} \\
4.98 \%\end{array}$ & $\begin{array}{c}165.00 \\
\mathrm{a} \\
3.32 \%\end{array}$ & $\begin{array}{c}66.90 \mathrm{a} \\
1.35 \%\end{array}$ & G6 & $\begin{array}{c}6750.30 \\
\mathrm{a} \\
71.63 \%\end{array}$ & $\begin{array}{c}956.47 \\
a \\
10.15 \%\end{array}$ & $\begin{array}{c}653.87 \\
\mathrm{~b} \\
6.94 \%\end{array}$ & $\begin{array}{c}561.99 \\
\text { a } \\
5.96 \%\end{array}$ & $\begin{array}{c}331.25 \\
\mathrm{a} \\
3.51 \%\end{array}$ & $\begin{array}{c}120.72 \\
\mathrm{a} \\
1.28 \%\end{array}$ & R5 & $\begin{array}{c}7188.79 \\
a \\
72.43 \%\end{array}$ & $\begin{array}{c}784.60 \\
\mathrm{a} \\
7.91 \%\end{array}$ & $\begin{array}{c}981.54 \\
\text { b } \\
9.89 \%\end{array}$ & $\begin{array}{c}445.11 \\
\mathrm{a} \\
4.48 \%\end{array}$ & $\begin{array}{c}323.07 \\
a \\
3.26 \%\end{array}$ & $\begin{array}{c}164.03 \\
\mathrm{a} \\
1.65 \%\end{array}$ \\
\hline Total & 4407.27 & 697.45 & 447.38 & 315.37 & 187.13 & 91.03 & Total & 7934.43 & 1338.42 & 763.81 & 687.47 & 402.32 & 179.73 & Total & 7958.22 & 992.97 & 996.92 & 512.18 & 384.20 & 203.16 \\
\hline $\begin{array}{c}p- \\
\text { value }\end{array}$ & 0.0003 & 0.0047 & 0.0251 & 0.0026 & 0.007 & 0.0024 & $\begin{array}{c}p- \\
\text { value }\end{array}$ & 0.0012 & 0.0002 & 0.2007 & 0.0009 & 0.0001 & 0.0002 & $\begin{array}{c}p- \\
\text { value }\end{array}$ & 0.1335 & 0.0879 & 0.0021 & 0.004 & 0.1973 & 0.0152 \\
\hline
\end{tabular}




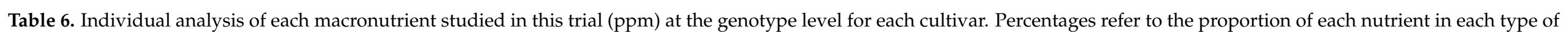

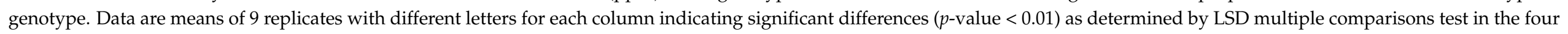
genotypes analyzed per cultivar ( $p$-value).

\begin{tabular}{|c|c|c|c|c|c|c|c|c|c|c|c|c|c|c|}
\hline CHD & $\mathrm{Fe}$ & Mn & $\mathrm{Zn}$ & $\mathrm{Cu}$ & GOAK & $\mathrm{Fe}$ & Mn & $\mathrm{Zn}$ & $\mathrm{Cu}$ & ROAK & $\mathrm{Fe}$ & Mn & $\mathrm{Zn}$ & $\mathrm{Cu}$ \\
\hline \multirow{2}{*}{$\mathrm{C} 1$} & $15.43 \mathrm{a}$ & $11.34 \mathrm{~b}$ & $6.15 b$ & $0.75 \mathrm{~b}$ & \multirow{2}{*}{ G1 } & $28.40 \mathrm{a}$ & $13.17 \mathrm{a}$ & $6.09 \mathrm{a}$ & $0.92 \mathrm{a}$ & \multirow{2}{*}{$\mathrm{R} 2$} & $31.74 \mathrm{a}$ & $14.83 \mathrm{~b}$ & $3.83 \mathrm{a}$ & $0.53 \mathrm{a}$ \\
\hline & $0.20 \%$ & $0.15 \%$ & $0.08 \%$ & $0.01 \%$ & & $0.28 \%$ & $0.13 \%$ & $0.06 \%$ & $0.01 \%$ & & $0.30 \%$ & $0.14 \%$ & $0.04 \%$ & $0.01 \%$ \\
\hline \multirow{2}{*}{$\mathrm{C} 3$} & $11.73 \mathrm{a}$ & $5.54 \mathrm{a}$ & $4.01 \mathrm{a}$ & $0.50 \mathrm{a}$ & \multirow{2}{*}{ G3 } & $49.52 \mathrm{~b}$ & $23.19 \mathrm{~b}$ & $10.37 \mathrm{~b}$ & $1.59 \mathrm{~b}$ & \multirow{2}{*}{ R3 } & $25.85 \mathrm{a}$ & $11.85 \mathrm{ab}$ & $4.81 \mathrm{a}$ & $0.64 \mathrm{a}$ \\
\hline & $0.22 \%$ & $0.10 \%$ & $0.08 \%$ & $0.01 \%$ & & $0.32 \%$ & $0.15 \%$ & $0.07 \%$ & $0.01 \%$ & & $0.26 \%$ & $0.12 \%$ & $0.05 \%$ & $0.01 \%$ \\
\hline \multirow{2}{*}{$\mathrm{C} 7$} & $17.34 \mathrm{a}$ & $7.34 \mathrm{a}$ & $4.32 \mathrm{a}$ & $0.52 \mathrm{a}$ & \multirow{2}{*}{ G5 } & $27.97 \mathrm{a}$ & $12.07 \mathrm{a}$ & $6.67 \mathrm{a}$ & $1.12 \mathrm{ab}$ & \multirow[b]{2}{*}{$\mathrm{R} 4$} & $27.05 \mathrm{a}$ & $11.47 \mathrm{ab}$ & $6.44 \mathrm{a}$ & $0.79 \mathrm{a}$ \\
\hline & $0.25 \%$ & $0.11 \%$ & $0.06 \%$ & $0.01 \%$ & & $0.28 \%$ & $0.12 \%$ & $0.07 \%$ & $0.01 \%$ & & $0.20 \%$ & $0.09 \%$ & $0.05 \%$ & $0.01 \%$ \\
\hline \multirow{2}{*}{$\mathrm{C} 8$} & $12.57 \mathrm{a}$ & $6.72 \mathrm{a}$ & $4.59 \mathrm{a}$ & $0.50 \mathrm{a}$ & \multirow{2}{*}{ G6 } & $28.80 \mathrm{a}$ & $13.61 \mathrm{a}$ & $6.31 \mathrm{a}$ & $1.12 \mathrm{ab}$ & \multirow{2}{*}{ R5 } & $22.87 \mathrm{a}$ & $8.24 \mathrm{a}$ & $5.53 \mathrm{a}$ & $0.69 \mathrm{a}$ \\
\hline & $0.25 \%$ & $0.14 \%$ & $0.09 \%$ & $0.01 \%$ & & $0.31 \%$ & $0.14 \%$ & $0.07 \%$ & $0.01 \%$ & & $0.23 \%$ & $0.08 \%$ & $0.06 \%$ & $0.01 \%$ \\
\hline Total & 14.27 & 7.74 & 4.77 & 0.57 & Total & 33.67 & 15.51 & 7.36 & 1.19 & Total & 26.50 & 11.25 & 5.32 & 0.68 \\
\hline$p$-value & 0.051 & 0.0025 & 0.0235 & 0.0147 & $p$-value & 0.0016 & 0.0003 & 0.0026 & 0.0214 & $p$-value & 0.3675 & 0.1888 & 0.1744 & 0.2709 \\
\hline
\end{tabular}


We wondered whether differences in nutrient levels between mature and juvenile leaves could account for the observed differences in tipburn scores and tipburn incidence in the GOAK and ROAK genotypes (Figure 6a,b). We found that G1 and R5, with the lowest tipburn scores, showed a mild decrease in $\mathrm{K}, \mathrm{Ca}, \mathrm{Mg}, \mathrm{Fe}$, and $\mathrm{Mn}$ concentrations between mature and juvenile leaves (Figure 7). The genotypes with the highest tipburn scores, G3 and R2, showed higher differences in $\mathrm{K}, \mathrm{Ca}, \mathrm{Mg}$, Fe, and $\mathrm{Mn}$ concentrations between mature and juvenile leaves (Figure 7). A similar trend was found for $\mathrm{S}$ and $\mathrm{Cu}$, although the R2 genotype showed higher $\mathrm{S}$ and $\mathrm{Cu}$ levels in juvenile leaves than the other three genotypes (Figure 7). Na concentration was also higher in mature leaves, and their levels were similarly reduced in juvenile leaves in the four genotypes (Figure 7). On the other hand, P and $\mathrm{Zn}$ showed the highest levels in juvenile leaves except for the G3 genotype (Figure 7).

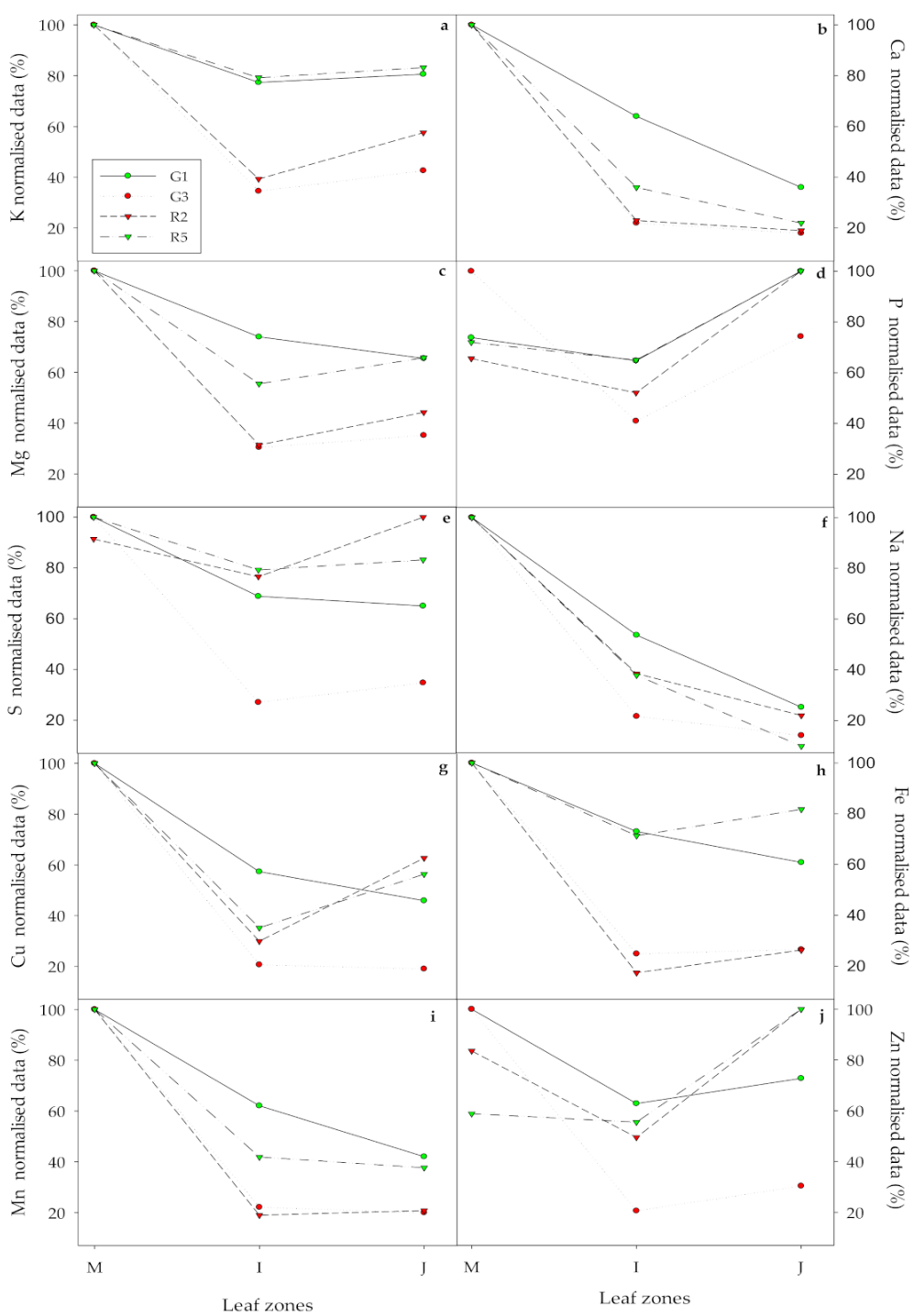

Figure 7. Nutrient analysis of the studied macronutrients in different leaves (M, mature; I, intermediate; J, juvenile). Only the most divergent genotypes for tipburn scoring and tipburn incidence for GOAK (G1 and G3) and ROAK (R2 and R5) cultivars are shown. The nutrients analyzed were (a) Potassium (K), (b) Calcium (Ca), (c) Magnesium (Mg), (d) Phosphorus (P), (e) Sulphur (S), (f) Sodium (Na), (g) Copper $(\mathrm{Cu})$, (h) Iron (Fe), (i) Manganese (Mn) and (j) Zinc (Zn). Data are normalized as regards the leaf with the highest amount for a given nutrient. 


\section{Discussion}

There is an increased demand for fresh, locally grown, and safe vegetables among the EU consumers [38]. However, intensive agricultural exploitation might lead to water shortage and soil salinization, among other environmental damages [39]. The greenhouse production of vegetables in closed hydroponic systems is a resource-efficient technique for the production of high-quality and high-yield crops [40]. Here, we devised a low-cost hydroponic system (i.e., floating rafts) for lettuce cultivation, which was used to evaluate the early growth and quality parameters of 12 genotypes from different lettuce cultivars (CHD, GOAK, and ROAK) in three growing seasons (Fall, Winter, and Spring). These genotypes were selected based on agronomically-relevant traits.

Research on the role of root system architecture (RSA) traits that could enhance nutrient and water use efficiency has not received broad attention in lettuce breeding programs until quite recently [6]. We found striking differences among the studied lettuce cultivars in regard to their root system (Figure 2a,c, Figure 3a,c, and Figure 4a,c). The CHD genotypes showed deeper roots as compared to those from GOAK and ROAK. As it is known that deeper roots are crucial for improving drought resistance in plants [41,42], CHD cultivars may be more drought tolerant than GOAK and ROAK genotypes, although this hypothesis could not be directly tested in our hydroponics system. On the other hand, GOAK and ROAK root systems were heavier and more superficial than those in the CHD cultivar. Indeed, GOAK and ROAK are oak-leaf cultivars located on the same genetic clade [43], which are mainly differentiated by their leaf anthocyanin content [1]. The differences in the RSA of the CHD and GOAK/ROAK cultivars may thus account for the genotype-dependent behavior of cultivated lettuce in saline soils [44] or in response to water and nutrient deficiency [6]. Our experimental setup will allow evaluating growth responses under different soil stresses through the adjustment of the nutrient solution and/or the experimental conditions (i.e., temperature, aeration, etc.). In addition, the contrasting RSA phenotypes of the G3 and R5 genotypes (Figures $3 c$ and $4 c$ ), with a threefold difference in their root fresh-weight during the Spring season (Figure 5), may be used for the identification of the genetic determinants involved in RSA variation in the oak-leaf lettuce clade through the implementation of QTL mapping. We estimated the shoot growth rates of lettuce in hydroponic culture through dedicated image analysis (Figure S2). Overall, shoot growth was much lower during Winter than in Spring or Fall, which is in agreement with previous studies where higher temperatures and high irradiance were found to be key factors, which affected growth product quality in these species [16,22]. However, we found an interesting $\mathrm{G} \times \mathrm{E}$ interaction for the estimated SA in some of the studied genotypes. On the one hand, the ROAK genotypes showed lower SA values in Spring than in Winter (Figure $4 \mathrm{~b}$ ). On the other hand, SA values in C7 were highly affected by the growing season, as higher growth occurred during Spring for this genotype (Figure $2 b$ ). However, the SA and RA values estimated from images were inaccurate descriptors of yield, as confirmed by the low correlations found between FW and DW values of the shoot system and the root system at the end of the experiment (Figure S6). We found that FW was highly correlated with DW (both for root or shoot) for all the studied cultivars and during the different growing seasons (Figure S6), and that their WC variation ranged from $92 \%$ to $98 \%$ (Table S4). Interestingly, we found that WC (either in roots or shoots) was negatively correlated with root DW but not with shoot DW, which suggest that thinner roots may be more efficient in water uptake in lettuce plants grown in hydroponics, as compared to those plants grown in soil where root diameter may be directly related to the ability to penetrate the drying soil [41]. In addition, the R:S ratio allowed us to identify genotypes with contrasting yield genotypes, such as C7 and R3 (Table S4). While C7 had the lowest $R: S$ values (and hence higher yield) in Fall, R3 showed the highest R:S ratio (thus lower yield) during Spring, indicating a $\mathrm{G} \times \mathrm{E}$ interaction for this trait, as well.

In Spain and Italy, two of the fifth largest lettuce and chicory producers in the world [11], greenhouse lettuce production is often limited by the extent of tipburn and premature bolting. Tipburn is a physiological disorder characterized by necrotic lesions at 
the margins of the developing leaves, resulting from a localized Ca deficiency [45]. Tipburn development in lettuce depends on environmental factors that promote growth [46]. Ca translocation from the roots to the shoots occurs through the xylem due to transpiration, and Ca cannot be mobilized from older leaves to younger ones [47]. Some of the climatic factors that characterize the Mediterranean region, specifically high temperature, high radiation, and long photoperiod, lead to the rapid shoot growth of lettuce, which cannot match Ca translocation from the roots. The lettuce genotypes studied in this work were selected based on their contrasting tipburn incidence when grown in soil. A previous study using a small number of lettuce cultivars grown in hydroponics showed that tipburn was not observed in the late Winter season, whereas it was severe during Spring [48]. We found that tipburn incidence was higher during Spring but lower in Winter for most of the studied cultivars grown in hydroponics (Figure 6a). And we also observed that the CHD cultivars showed a higher variation for tipburn incidence as compared to the studied oak-leaf types (GOAK and ROAK). These results were consistent with the greater genetic variability for tipburn responses found in the CHD cultivar as a result of earlier breeding efforts for tipburn tolerance in this cultivar [19,22,24,25]. In a recent study [28], early bolting and tipburn behavior were studied on 18 genotypes from different lettuce cultivars grown in hydroponics at high temperature and extensive differences were also observed among them. Hence, the combined effect of high growth rates and high temperatures during Spring may lead to the reduced nutrient supply to the developing leaves, resulting in the observed enhancement of the tipburn severity during Spring. Only two of the studied genotypes, C3 and R2 showed severe tipburn symptoms in every season (Figure 6a,c). Another two genotypes, C8 and G3 showed intermediate-to-severe tipburn symptoms only during Spring (Figure 6a,c). On the other hand, C1, G1, and R5 showed tipburn tolerance when grown in hydroponics (Figure $6 \mathrm{a}, \mathrm{c}$ ). These results perfectly matched the tipburn severity symptoms found in the studied genotypes when grown in soil (V.B., unpublished), which validates our experimental setup for the fast and high-throughput evaluation of tipburn responses in lettuce germplasm collections grown in hydroponics.

To investigate the nutritional causes of tipburn incidence during Spring in the studied genotypes, we measured the levels of several macro and micronutrients in leaves of different ages at the end of the experiment (45 dap; Table S6). Ca and Na levels showed the highest $\mathrm{M} / \mathrm{J}$ ratio, irrespectively of the cultivar type (Table 2), which is consistent with the low Ca mobilization from mature tissues [45] and the higher Na accumulation in older leaves [49]. On the other hand, P displayed the lowest $\mathrm{M} / \mathrm{J}$ values within the studied macronutrients (Table 2), with lower P levels in the CHD than in the GOAK/ROAK genotypes. These latter results could be explained by the differences in RSA between the studied cultivars, as root responses to low phosphate favor the exploration of the shallower part of the soil, where phosphate tends to be more abundant [50]. We noticed that the CHD genotypes contained a lower nutrient concentration than the GOAK and ROAK ones (Table 4). Nutritional differences between lettuce cultivars have been described previously [51]. The tipburn incidence and tipburn scores of the CHD genotypes perfectly matched their total nutrient content, hence, the genotypes with the lowest nutrient levels (C3 and C8) showed severe tipburn symptoms (Figure 6a,b and Tables 5 and 6). Our results suggest that tipburn in the studied CHD genotypes may be related to some nutrient imbalance, as has been proposed earlier in lettuce [52]. The high growth rates observed during Spring for C3 and C8, combined with their contrasting R:S ratios, may result in decreased $\mathrm{Ca}$ concentrations in leaves and thus increased tipburn, as has been previously reported in other lettuce genotypes [21,45]. Because of the restricted Ca transport within the head-enclosed leaves of the CHD genotypes, Ca levels are much lower in the leaf margins, where tipburn symptoms arise early; high $\mathrm{K}$ levels in this region might also contribute to enhanced tipburn in CHD genotypes, as suggested previously [45]. Overall, the studied ROAK and GOAK genotypes were less sensitive to tipburn, which was consistent with previous results which suggested a narrow genetic variation for this trait in oak-leaf type cultivars [19]. R2 and G3, which displayed severe tipburn during the Spring season, were 
characterized by a strong decrease in $\mathrm{K}$ levels between mature and juvenile leaves, as compared with the tipburn tolerant G1 and R5 genotypes (Figure 7). To assess whether tipburn in the studied lettuce genotypes is caused by an altered $\mathrm{Ca} / \mathrm{K}$ homeostasis, we plan to evaluate tipburn susceptibility using an in vitro evaluation system [24], with some modifications.

We also found striking differences in regard to the studied micronutrients (Fe, $\mathrm{Mn}$, $\mathrm{Zn}$, and $\mathrm{Cu}$ ) depending on cultivar type and genotypes (Tables 3 and 6). Alterations in micronutrient homeostasis (such as Fe and Mn) have commonly been associated with the appearance of shoot tip necrosis during pistachio in vitro culture [53], which very much resembles the tipburn symptoms found in the ROAK and GOAK genotypes. Fe and Mn levels in leaves, as well as their M/J ratios, were much higher in the GOAK and ROAK genotypes than in the CHD ones (Table 3). Consistent with previous results on K levels, Fe and Mn levels strongly decreased in the R2 and G3 genotypes from mature to juvenile leaves (Figure 7), suggesting that a nutritional unbalance of some micronutrients (Fe and $\mathrm{Mn}$ ) could explain tipburn in oak-leaf susceptible genotypes. Further experiments with additional ROAK and GOAK genotypes will allow us to confirm this hypothesis.

\section{Conclusions}

We devised a multi-factorial approach for the study of several growth and quality traits of lettuce (Lactuca sativa L.) using a low-cost and high-throughput scalable hydroponic system. By analyzing tipburn incidence and leaf nutrient content, we were able to identify a number of nutrient traits that were highly correlated with cultivar- and genotypedependent tipburn, suggesting that tipburn is a complex trait in this species. Indeed, the genetic dissection of tipburn resistance in lettuce has recently gained from a detailed study using seven RIL populations in multiple environments and years that allowed the identification of two major QTL affecting this trait [26]. The forthcoming availability of linked molecular markers will allow the evaluation of our germplasm collection.

Supplementary Materials: The following are available online at https: / /www.mdpi.com/2073-4 395/11/4/616/s1, Figure S1: A representation of the scale used for tipburn severity assessment; Figure S2: The growth rate of the studied cultivars between 0 and 35 dap; Figure S3: Representative images of the studied CHD genotypes; Figure S4: Representative images of the studied GOAK genotypes; Figure S5: Representative images of the studied ROAK genotypes; Figure S6: Growth quantification of the studied genotypes at 45 dap; Table S1: Details of the experimental design used; Table S2: Nutrient solution composition; Table S3:, Raw data of root and shoot area; Table S4: raw data of root and shoot weights; Table S5, Raw data of tipburn phenotype assessment, Table S6: Raw data of the nutrient analysis.

Author Contributions: Conceptualization, V.B., J.R.A.-M., and J.M.P.-P.; data curation, V.B. and J.R.A.M.; funding acquisition, J.M.P.-P.; investigation, V.B.; methodology, V.B. and J.R.A.-M.; supervision, J.M.P.-P.; validation, V.B., J.R.A.-M., and J.M.P.-P.; writing-original draft, J.R.A.-M. and J.M.P.-P.; writing-review and editing, V.B., J.R.A.-M., and J.M.P.-P. All authors have read and agreed to the published version of the manuscript.

Funding: This research received no external funding.

Institutional Review Board Statement: Not applicable.

Informed Consent Statement: Not applicable.

Data Availability Statement: The data presented in this study are available online at www.mdpi. $\mathrm{com} / \mathrm{xxx} / \mathrm{s} 1$.

Acknowledgments: We are grateful to María José Ñíguez Gómez (Universidad Miguel Hernández) for her expert technical assistance, Jorge Benítez Vega (Bayer CropScience) for his support in the experimental designs and genotype information, José Antonio Hernández for his help with nutrient analyses at the CEBAS-CSIC Ionomics laboratory and Mario Fon for his help with English editing.

Conflicts of Interest: The authors declare no conflict of interest. 


\section{References}

1. Hayes, R.J.; Simko, I. Breeding lettuce for improved fresh-cut processing. Acta Hortic. 2016, 65-76. [CrossRef]

2. Patella, A.; Palumbo, F.; Galla, G.; Barcaccia, G. The Molecular Determination of Hybridity and Homozygosity Estimates in Breeding Populations of Lettuce (Lactuca sativa L.). Genes 2019, 10, 916. [CrossRef]

3. Truco, M.J.; Antonise, R.; Lavelle, D.; Ochoa, O.; Kozik, A.; Witsenboer, H.; Fort, S.B.; Jeuken, M.J.W.; Kesseli, R.V.; Lindhout, P.; et al. A high-density, integrated genetic linkage map of lettuce (Lactuca spp.). Theor. Appl. Genet. 2007, 115, 735-746. [CrossRef]

4. Truco, M.J.; Ashrafi, H.; Kozik, A.; van Leeuwen, H.; Bowers, J.; Wo, S.R.C.; Stoffel, K.; Xu, H.; Hill, T.; Van Deynze, A.; et al. An Ultra-High-Density, Transcript-Based, Genetic Map of Lettuce. G3 Genes Genomes Genet. 2013, 3, 617-631. [CrossRef]

5. Rauscher, G.; Simko, I. Development of genomic SSR markers for fingerprinting lettuce (Lactuca sativa L.) cultivars and mapping genes. BMC Plant Biol. 2013, 13, 11. [CrossRef]

6. Kerbiriou, P.J.; Maliepaard, C.A.; Stomph, T.J.; Koper, M.; Froissart, D.; Roobeek, I.; Lammerts Van Bueren, E.T.; Struik, P.C. Genetic Control of Water and Nitrate Capture and Their Use Efficiency in Lettuce (Lactuca sativa L.). Front. Plant Sci. $2016,7,343$. [CrossRef]

7. Yoong, F.-Y.; O’Brien, L.K.; Truco, M.J.; Huo, H.; Sideman, R.; Hayes, R.; Michelmore, R.W.; Bradford, K.J. Genetic Variation for Thermotolerance in Lettuce Seed Germination Is Associated with Temperature-Sensitive Regulation of ethylene response factor1 (ERF1). Plant Physiol. 2016, 170, 472-488. [CrossRef]

8. Damerum, A.; Selmes, S.L.; Biggi, G.F.; Clarkson, G.J.; Rothwell, S.D.; Truco, M.J.; Michelmore, R.W.; Hancock, R.D.; Shellcock, C.; Chapman, M.A.; et al. Elucidating the genetic basis of antioxidant status in lettuce (Lactuca sativa). Hortic. Res. 2015, 2, 15055. [CrossRef]

9. Simko, I.; Hayes, R.J.; Mou, B.; McCreight, J.D. Lettuce and Spinach. In CSSA Special Publications; Smith, S., Diers, B., Specht, J., Carver, B., Eds.; American Society of Agronomy and Soil Science Society of America: Madison, WI, USA, 2015; pp. 53-85. ISBN 978-0-89118-619-9. [CrossRef]

10. Atkinson, L.D.; McHale, L.K.; Truco, M.J.; Hilton, H.W.; Lynn, J.; Schut, J.W.; Michelmore, R.W.; Hand, P.; Pink, D.A.C. An intra-specific linkage map of lettuce (Lactuca sativa) and genetic analysis of postharvest discolouration traits. Theor. Appl. Genet. 2013, 126, 2737-2752. [CrossRef]

11. Food and Agriculture Organization of the United Nations. FAOSTAT Statistical Database; FAO: Rome, Italy, 2019; Available online: http:/ / www.fao.org/faostat/es/\#data/QC/metadata (accessed on 15 January 2021).

12. Romero-Gámez, M.; Audsley, E.; Suárez-Rey, E.M. Life cycle assessment of cultivating lettuce and escarole in Spain. J. Clean. Prod. 2014, 73, 193-203. [CrossRef]

13. Guaita-García, N.; Martínez-Fernández, J.; Barrera-Causil, C.J.; Esteve-Selma, M.Á.; Fitz, H.C. Local perceptions regarding a social-ecological system of the mediterranean coast: The Mar Menor (Región de Murcia, Spain). Environ. Dev. Sustain. 2020, 23, 2882-2909. [CrossRef]

14. Coronel, G.; Chang, M.; Rodríguez-Delfín, A. Nitrate reductase activity and chlorophyll content in lettuce plants grown hydroponically and organically. Acta Hortic. 2009, 137-144. [CrossRef]

15. Kotsiras, A.; Vlachodimitropoulou, A.; Gerakaris, A.; Bakas, N.; Darras, A.I. Innovative harvest practices of Butterhead, Lollo rosso and Batavia green lettuce (Lactuca sativa L.) types grown in floating hydroponic system to maintain the quality and improve storability. Sci. Hortic. 2016, 201, 1-9. [CrossRef]

16. Petropoulos, S.A.; Chatzieustratiou, E.; Constantopoulou, E.; Kapotis, G. Yield and Quality of Lettuce and Rocket Grown in Floating Culture System. Not. Bot. Hortic. Agrobot. 2016, 44, 603-612. [CrossRef]

17. Saure, M.C. Causes of the tipburn disorder in leaves of vegetables. Sci. Hortic. 1998, 76, 131-147. [CrossRef]

18. Frantz, J.M.; Ritchie, G.; Cometti, N.N.; Robinson, J.; Bugbee, B. Exploring the Limits of Crop Productivity: Beyond the Limits of Tipburn in Lettuce. J. Am. Soc. Hortic. Sci. 2004, 129, 331-338. [CrossRef]

19. Jenni, S.; Hayes, R.J. Genetic variation, genotype $\times$ environment interaction, and selection for tipburn resistance in lettuce in multi-environments. Euphytica 2010, 171, 427-439. [CrossRef]

20. Lee, J.G.; Choi, C.S.; Jang, Y.A.; Jang, S.W.; Lee, S.G.; Um, Y.C. Effects of air temperature and air flow rate control on the tipburn occurrence of leaf lettuce in a closed-type plant factory system. Hortic. Environ. Biotechnol. 2013, 54, 303-310. [CrossRef]

21. Sago, Y. Effects of Light Intensity and Growth Rate on Tipburn Development and Leaf Calcium Concentration in Butterhead Lettuce. HortScience 2016, 51, 1087-1091. [CrossRef]

22. Jenni, S.; Yan, W. Genotype by environment interactions of heat stress disorder resistance in crisphead lettuce. Plant Breed. 2009, 128, 374-380. [CrossRef]

23. Ryder, E.J.; Waycott, W. Crisphead lettuce resistant to tipburn: Cultivar tiber and eight breeding lines. HortScience 1998, 33, 903-904. [CrossRef]

24. Koyama, R.; Sanada, M.; Itoh, H.; Kanechi, M.; Inagaki, N.; Uno, Y. In vitro evaluation of tipburn resistance in lettuce (Lactuca sativa. L). Plant Cell Tissue Organ. Cult. 2012, 108, 221-227. [CrossRef]

25. Jenni, S.; Truco, M.J.; Michelmore, R.W. Quantitative trait loci associated with tipburn, heat stress-induced physiological disorders, and maturity traits in crisphead lettuce. Theor. Appl. Genet. 2013, 126, 3065-3079. [CrossRef]

26. Macias-González, M.; Truco, M.J.; Bertier, L.D.; Jenni, S.; Simko, I.; Hayes, R.J.; Michelmore, R.W. Genetic architecture of tipburn resistance in lettuce. Theor. Appl. Genet. 2019, 132, 2209-2222. [CrossRef] 
27. Carassay, L.R.; Bustos, D.A.; Golberg, A.D.; Taleisnik, E. Tipburn in salt-affected lettuce (Lactuca sativa L.) plants results from local oxidative stress. J. Plant Physiol. 2012, 169, 285-293. [CrossRef]

28. Holmes, S.C.; Wells, D.E.; Pickens, J.M.; Kemble, J.M. Selection of Heat Tolerant Lettuce (Lactuca sativa L.) Cultivars Grown in Deep Water Culture and Their Marketability. Horticulturae 2019, 5, 50. [CrossRef]

29. Incrocci, L.; Moolhuyzen, M.; Guzmán, M. Nutrient Solution Calculator ES; IFAPA: Almería, Spain, 2020. [CrossRef]

30. Berry, W.L.; Knight, S. Plant Culture in Hydroponics; Iowa State University: Ames, IA, USA, 1997; pp. $119-131$.

31. Galkovskyi, T.; Mileyko, Y.; Bucksch, A.; Moore, B.; Symonova, O.; Price, C.A.; Topp, C.N.; IyerPascuzzi, A.S.; Zurek, P.R.; Fang, S.; et al. GiA Roots: Software for the high throughput analysis of plant root system architecture. BMC Plant Biol. 2012, 12, 116. [CrossRef]

32. Birlanga, V.; Villanova, J.; Cano, A.; Cano, E.A.; Acosta, M. Quantitative Analysis of Adventitious Root Growth Phenotypes in Carnation Stem Cuttings. PLoS ONE 2015, 10, e0133123. [CrossRef]

33. Schneider, C.A.; Rasband, W.S.; Eliceiri, K.W. NIH Image to ImageJ: 25 years of image analysis. Nat. Methods 2012, 9, 671-675. [CrossRef] [PubMed]

34. Acosta-Motos, J.R.; Hernández, J.A.; Álvarez, S.; BarbaEspín, G.; SánchezBlanco, M.J. The long term resistance mechanisms, critical irrigation threshold and relief capacity shown by Eugenia myrtifolia plants in response to saline reclaimed water. Plant Physiol. Biochem. 2017, 111, 244-256. [CrossRef] [PubMed]

35. Massey, F. The Kolmogorov Smirnov test for goodness of fit. J. Am. Stat. Assoc. 1951, 46, 253. [CrossRef]

36. Fisher, R. The correlation between relatives on the supposition of Mendelian inheritance. Trans. R. Soc. Edinb. 1918, 52, 399-433. [CrossRef]

37. The R Project for Statistical Computing. Available online: https:/ /www.r-project.org/ (accessed on 2 February 2021).

38. Baselice, A.; Colantuoni, F.; Lass, D.A.; Nardone, G.; Stasi, A. Trends in EU consumers' attitude towards fresh-cut fruit and vegetables. Food Qual. Prefer. 2017, 59, 87-96. [CrossRef]

39. Gomiero, T. Soil Degradation, Land Scarcity and Food Security: Reviewing a Complex Challenge. Sustainability 2016, 8, 281. [CrossRef]

40. Hosseinzadeh, S.; Bonarrigo, G.; Verheust, Y.; Roccaro, P.; Van Hulle, S. Water reuse in closed hydroponic systems: Comparison of GAC adsorption, ion exchange and ozonation processes to treat recycled nutrient solution. Aquac. Eng. 2017, 78, 190-195. [CrossRef]

41. Lynch, J.P.; Chimungu, J.G.; Brown, K.M. Root anatomical phenes associated with water acquisition from drying soil: Targets for crop improvement. J. Exp. Bot. 2014, 65, 6155-6166. [CrossRef] [PubMed]

42. Acosta-Motos, J.R.; Rothwell, S.A.; Massam, M.J.; Albacete, A.; Zhang, H.; Dodd, I.C. Alternate wetting and drying irrigation increases water and phosphorus use efficiency independent of substrate phosphorus status of vegetative rice plants. Plant Physiol. Biochem. 2020, 155, 914-926. [CrossRef] [PubMed]

43. Simko, I. Development of EST-SSR Markers for the Study of Population Structure in Lettuce (Lactuca sativa L.). J. Hered. 2009, 100, 256-262. [CrossRef] [PubMed]

44. Xu, C.; Mou, B. Evaluation of Lettuce Genotypes for Salinity Tolerance. HortScience 2015, 50, 1441-1446. [CrossRef]

45. Barta, D.J.; Tibbitts, T.W. Calcium Localization and Tipburn Development in Lettuce Leaves during Early Enlargement. J. Am. Soc. Hortic. Sci. 2000, 125, 294-298. [CrossRef] [PubMed]

46. Wissemeier, A.H.; Zühlke, G. Relation between climatic variables, growth and the incidence of tipburn in field-grown lettuce as evaluated by simple, partial and multiple regression analysis. Sci. Hortic. 2002, 93, 193-204. [CrossRef]

47. Gilliham, M.; Dayod, M.; Hocking, B.J.; Xu, B.; Conn, S.J.; Kaiser, B.N.; Leigh, R.A.; Tyerman, S.D. Calcium delivery and storage in plant leaves: Exploring the link with water flow. J. Exp. Bot. 2011, 62, 2233-2250. [CrossRef]

48. Assimakopoulou, A.; Kotsiras, A.; Nifakos, K. Incidence of lettuce tipburn as related to hydroponic system and cultivaR. J. Plant Nutr. 2013, 36, 1383-1400. [CrossRef]

49. Almeida, D.M.; Oliveira, M.M.; Saibo, N.J.M. Regulation of Na+ and K+ homeostasis in plants: Towards improved salt stress tolerance in crop plants. Genet. Mol. Biol. 2017, 40, 326-345. [CrossRef]

50. Péret, B.; Desnos, T.; Jost, R.; Kanno, S.; Berkowitz, O.; Nussaume, L. Root Architecture Responses: In Search of Phosphate. Plant Physiol. 2014, 166, 1713-1723. [CrossRef]

51. Mou, B. Genetic Variation of Beta-carotene and Lutein Contents in Lettuce. J. Am. Soc. Hortic. Sci. 2005, 130, 870-876. [CrossRef]

52. Ashkar, S.A.; Ries, S.K. Lettuce tipburn as related to nutrient imbalance and nitrogen composition. J. Am. Soc. Hortic. Sci. 1971, 96, $448-452$.

53. Nezami-Alanagh, E.; Garoosi, G.-A.; Landín, M.; Gallego, P.P. Computer-based tools provide new insight into the key factors that cause physiological disorders of pistachio rootstocks cultured in vitro. Sci. Rep. 2019, 9, 9740. [CrossRef] [PubMed] 